\title{
Phytopathology"
}

\section{When Viruses Play Team Sports: Mixed Infections in Plants}

\author{
Ana Beatriz Moreno ${ }^{1}$ and Juan José López-Moya ${ }^{1,2, \dagger}$ \\ ${ }^{1}$ Centre for Research in Agricultural Genomics, Consejo Superior de Investigaciones Científicas IRTA-UAB-UB, Cerdanyola del Vallès, \\ Barcelona, Spain \\ ${ }^{2}$ Consejo Superior de Investigaciones Científicas, Barcelona, Spain \\ Accepted for publication 19 September 2019.
}

\begin{abstract}
The pathological importance of mixed viral infections in plants might be underestimated except for a few well-characterized synergistic combinations in certain crops. Considering that the host ranges of many viruses often overlap and that most plant species can be infected by several unrelated viruses, it is not surprising to find more than one virus simultaneously in the same plant. Furthermore, dispersal of the majority of plant viruses relies on efficient transmission mechanisms mediated by vector organisms, mainly but not exclusively insects, which can contribute to the occurrence of multiple infections in the same plant. Recent work using different experimental approaches has shown that mixed viral infections can be remarkably frequent, up to the point that they could be considered the rule more than the exception. The purpose of this review is to describe the impact of multiple infections not only on the participating viruses themselves but also on their vectors and on the common host. From this standpoint, mixed infections arise as complex events that involve several cross-interacting players, and they consequently require a more general perspective than the analysis of single-virus/single-host approaches for a full understanding of their relevance.
\end{abstract}

Keywords: disease control and pest management, virology

The diversity of viruses is extraordinary, as virtually all kinds of cellular life forms are susceptible to being parasitized by many different viruses; plants are no exception (Wolf et al. 2018). Plant viruses are grouped in numerous families (about 30) and genera $(>145)$ with extraordinary heterogeneity, which makes them one of the most abundant groups of pathogens responsible for a large number of all known plant diseases. For example, nearly 1,500 species are listed in the International Committee on Virus Taxonomy (2018) report. Our knowledge of the virosphere is currently facing a major challenge to classify and accommodate many recently discovered viruses (Koonin and Dolja 2018; Zhang et al. 2019). One of the reasons explaining why this enormous diversity was somehow overlooked until now comes from the fact

${ }^{\dagger}$ Corresponding author: J. J. López-Moya; juanjose.lopez@cragenomica.es

Funding: Research at the Centre for Research in Agricultural Genomics (CRAG) Laboratory of Virology is funded by the Spanish Ministerio de Economía y Competitividad (MINECO) (grant AGL2016-75529-R to J. J. López-Moya). A. B. Moreno received a European Union H2020 Marie Skłodowska-Curie Actions Individual Fellowship (H2020-MSCA-IF-2014 SEP-210187550). Support to CRAG from the MINECO Severo Ochoa Program (grant SEV-2015-0533) and from the Generalitat de Catalunya CERCA Institution is also acknowledged.

The author(s) declare no conflict of interest.

(c) 2020 The American Phytopathological Society that attention was mostly focused on agents of diseases and, in the case of plants, only viruses causing economic losses in crops and ornamentally valuable species have been deeply studied for decades. A particularly interesting case of this tendency to bias our knowledge is the frequent existence of mixed infections. This common situation was likely underestimated in available studies, with not as many reported examples, despite the fact that many plant viruses are generalists and thus able to infect different plants, including both crops and wild plants (Alexander et al. 2014; Elena et al. 2009). Furthermore, many vectors of plant viruses are polyphagous or are organisms associated with multiple hosts, capable of transmitting more than one virus to the same plant (Syller 2014). All of these conditions argue in favor of a more frequent presence of multiple viruses in plants; indeed, metagenomics approaches using high-throughput next-generation sequencing techniques have begun to reveal the real extent of mixed infections between known and occasionally unknown viruses in the virome in plant hosts, including wild plants and crops (Al Rwahnih et al. 2009; Mascia and Gallitelli 2016; Roossinck et al. 2010, 2015). Until relatively recently, symptomless wild plants were rarely studied, although work conducted on weeds and wild plants growing within or around crop fields often revealed the presence of multiple viruses. In addition, there are many reports deriving from surveys in crop plants that showed multiple viral infections in the examined samples. Unfortunately, these types of descriptive studies are frequently not complemented with work on 
the interactions occurring between the viruses involved, unless they were responsible for epidemics causing major crop losses. In addition, the technology to conduct global analysis was not broadly available until recently. Nevertheless, the new concept of the virome is finally gaining interest in the research community (including funding agencies) and logically, plant virologists are intensifying their efforts to describe "what is out there." Consequently, we believe that there will be more frequent detections of mixed viral infections in the coming years. Therefore, we think it is timely to review what it is known about mixed viral infections, acknowledging that they can be quite complex and that their establishment relies not only on the properties of each one of the actors involved (viruses, common host, and vector or vectors) but also on the relationship and interactions between them. Moreover, other layers of complexity can be added to multiple viral infections, such as the presence of natural enemies of the vectors or the influence of nonviral pathogens in the host plant. However, those aspects are explored elsewhere and are not addressed in this review (Dáder et al. 2012; Jeger et al. 2011a, b; Prager et al. 2015). Similarly, the importance of multipathogenic attacks (Abdullah et al. 2017) and even the combination of biotic and abiotic stresses in more holistic approaches (Saijo and Loo 2019) has come to researchers' attention. Nevertheless, we will concentrate here on the combination of heterologous viruses, although it is important to keep in mind that these cases are only a subset of many other putative relationships between the numerous sources of stress that plants must face.

Some mixed viral infections have been the cause of important diseases in crops worldwide, as they induce a decline in plant vigor and productivity. Logically, these cases have been studied in depth. A first example is corn or maize lethal necrosis (MLN), which affects one of the main crop species in the world and causes economically devastating losses. MLN results from the combination of the machlomovirus maize chlorotic mottle virus and different members of the family Potyviridae (Mahuku et al. 2015; Redinbaugh and Stewart 2018; Scheets 1998; Stewart et al. 2017; Uyemoto et al. 1980).

Sweet potato viral disease (SPVD) is another good example of the consequences of a well-characterized mixed viral infection (Clark et al. 2012). Sweet potato is considered a crop essential for food security in extended areas, as it is a basic dietary component for large populations in China and Africa. One of the peculiarities of sweet potato compared with most other crops is attributable to its rapid multiplication by vegetative propagation of cuttings, a rather beneficial agronomic trait that implies a high risk of accumulating pathogens, particularly viruses. Likely most marketable sweet potatoes are infected simultaneously by several viruses of the remarkably large list of $>30$ different viruses that can infect this plant. SPVD results from the synergistic interaction of isolates of the crinivirus Sweet potato chlorotic stunt virus (SPCSV) and the potyvirus Sweet potato feathery mottle virus (SPFMV) and can cause losses up to $90 \%$ of the crop yield (Karyeija et al. 2000). Another well-known viral combination in the same crop is sweet potato severe mosaic disease, caused again by synergism between SPCSV and the ipomovirus sweet potato mild mottle virus (SPMMV) (Mukasa et al. 2003; Tugume et al. 2005).

Cassava is also another important staple food crop with a high incidence of multiple viral infections. As in the case of sweet potato, the vegetative propagation is often perpetuating infections by many viruses (Jacobson et al. 2018; Legg et al. 2015; Rey and Vanderschuren 2017; Zinga et al. 2013). Research is revealing some particularly complex viral combinations on this host (Abarshi et al. 2012; Carvajal-Yepes et al. 2014; Reddy et al. 2012).

Another example of a crop with important problems caused by multiple viruses is grapevine. In this case, the cultivation method relying on grafting and propagation of clonal varieties also can favor mixed infections. Currently, approximately 70 viruses and virus-like agents have been documented in different grapevine cultivars worldwide (Martelli 2014). Grapevine leafroll disease is an extreme example of a multiple viral infection, as it is a complex disease caused by the association of up to 11 grapevine leafrollassociated viruses (Naidu et al. 2014, 2015).

In addition, some subviral agents or viral-associated replicons can be also considered examples of mixed infections. For instance, the alphasatellites associated with geminiviruses and nanoviruses (Briddon et al. 2018) were found to reduce infectivity in some cases and to either reduce or exacerbate symptoms and even to affect vector transmission (Mar et al. 2017). Another example are the small RNA replicons that often associate with poleroviruses, like the one associated with isolate ST9 of beet western yellows virus: this small RNA is replication competent but absolutely dependent on the helper virus for movement and aphid transmission (Falk and Duffus 1984; Falk et al. 1989). Interestingly, its presence stimulates the replication of the helper polerovirus and confers symptom severity (Passmore et al. 1993; Sanger et al. 1994). Although we will focus mainly on the interactions between viruses, we will also consider other associated agents in some cases.

All of the examples mentioned, together with the new knowledge that metagenomics approaches are bringing to the surface, reveal that mixed infections occur in a high frequency. However, a vast number of research efforts in plant virology still deal only with single infections. This might correspond to the difficulties and constraints of working with several pathogens at the same time from a methodological standpoint and also to the tendency to simplify questions, a logical first approach to any scientifically oriented endeavor. Undoubtedly, the field of plant virology has been (and still is) particularly successful in providing novel and valuable knowledge that extends to the adoption of valid control measures against many viral diseases. Yet in most cases, there are still complexities that remain to be elucidated (Sanfaçon 2017), and we believe it is timely to recognize the importance of mixed viral infections. Here, we aim to summarize a selection of the most relevant literature available about the topic, with emphasis on the outcomes for each of the players involved, and we focus mainly on plant viruses transmitted by insects because they represent the major group of plant virus vectors. Nevertheless, we include a few examples of viruses disseminated through contact, or even several cases in which subviral agents participate in multiple infections, as mentioned above. This review is organized in three parts, referring to the impact of mixed infections with respect to viruses, vectors, and host plants. However, as a note of caution, this separation was adopted only to facilitate the classification of topics, and it is important to keep in mind that mixed infections often require the participation of the three mentioned players. Thus, the expected effects of mixed infections most likely will have consequences on each of the players, as represented schematically in Figure 1. The concluding remarks include a general discussion of the implications of mixed viral infections, addressing their importance for the ecology of viruses and for the control strategies against viral pathogens.

\section{IMPACT ON VIRUSES}

During a mixed viral infection, the viruses involved may interact between themselves in a range that goes from synergism to neutralism to antagonism, having a direct impact on the plant host and also potentially on their relationships with vector organisms. The outcome depends on the different aspects and parameters evaluated, such as the within-host interactions between viruses or the virus adaptation to the host (Mascia and Gallitelli 2016; Syller 2012). When there are no changes in viral accumulation (or their dynamics) during the mixed infection compared with the single infections with the individual viruses, the interaction is often 
called neutral and the phenotypes (or symptoms in broad sense) can be the same as those observed in single infections, instead of the frequent occurrence of host responses with additive symptom expression (Mascia and Gallitelli 2016). On the other hand, if there are differences between the single and the mixed infections, the interactions can be classified as synergistic or antagonistic.

In a synergistic interaction, at least one of the viruses benefits from the presence of the other(s), which is manifested by an increase in the viral titer and/or pathogenicity (or other supra-level properties such as the capacity to disseminate efficiently by the vector organism) compared with a single infection. The resulting symptoms are often more severe than those observed in single infections of the same viruses. There are several reasons that could explain, individually or combined, this effect (see Figs. 2 and 3 for schematic representations). This effect can be caused by an increase in replication, by the ability to invade new plant tissues, or even by interference with plant defenses (particularly, but not necessarily uniquely, with post-transcriptional gene silencing mechanisms). Consequently, synergisms may have a high economic impact when they occur in crops because the resulting diseases are likely to become more severe. As an example, we can cite the serious epidemic of cassava mosaic disease, which is caused by a mixed infection between isolates of African cassava mosaic virus and isolates of the Uganda strain of East African

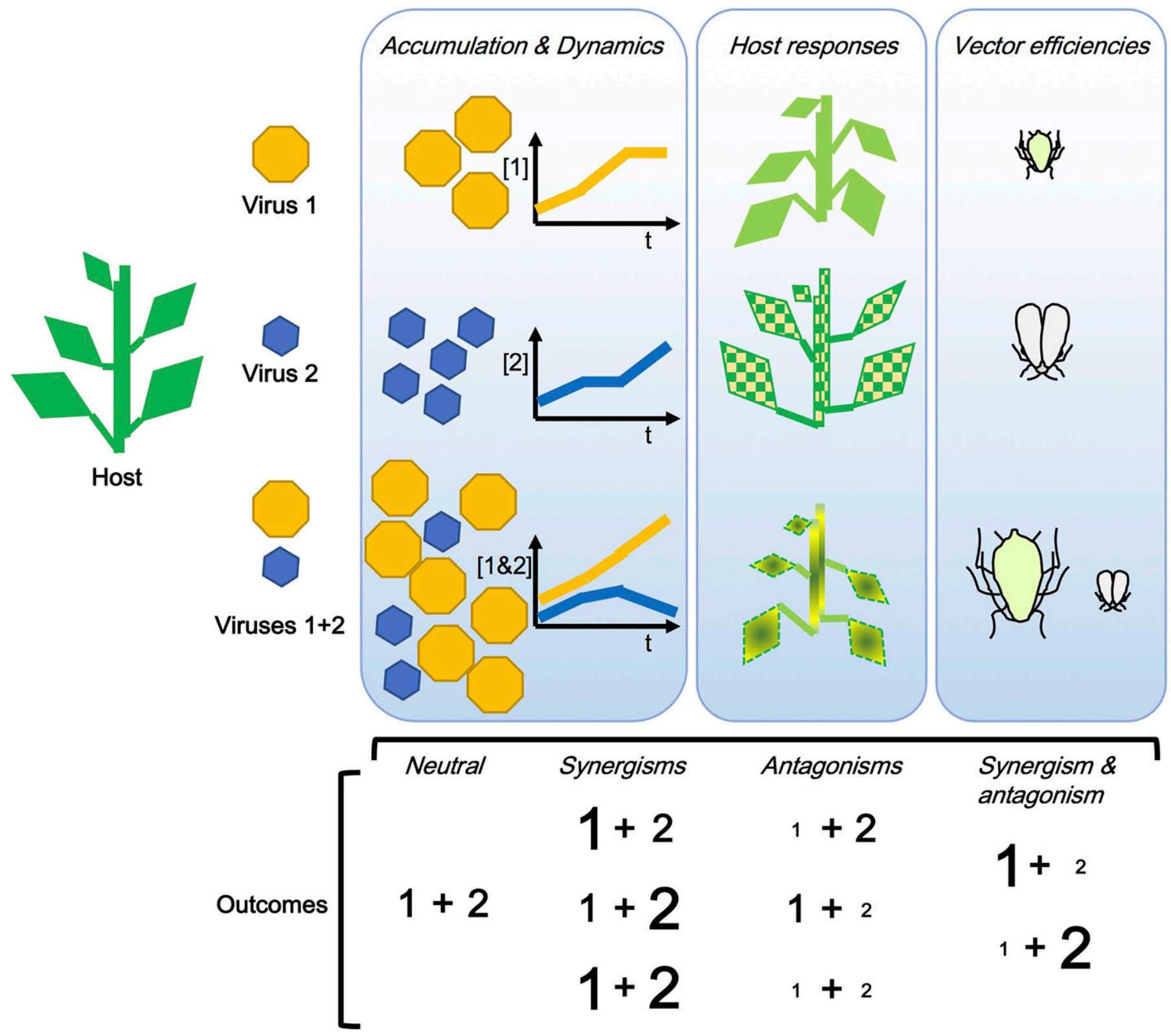

FIGURE 1

Different scenarios of interaction during mixed viral infections of plants. Responses in terms of virus accumulation and temporal dynamics (left column), degree of symptoms in the susceptible host (middle column), and efficiency of vector transmission (right column) are schematically represented, respectively, for the individual infections by virus 1 or virus 2 in the first and second rows. The third row proposes one of the possible outcomes of a mixed infection of viruses 1 and 2, with increased and faster accumulation of one of the viruses (represented by number of virions and inclination of curves), causing more damage to the plant (less growth and severe symptoms) and altering their vector dissemination (efficiency proportional to vector size). For each of the parameters, combined outcomes might differ as shown in the lower part of the figure, where the type size of the numerals represents neutral, synergistic, antagonistic, or both types of responses for each virus. See the text for further details. 


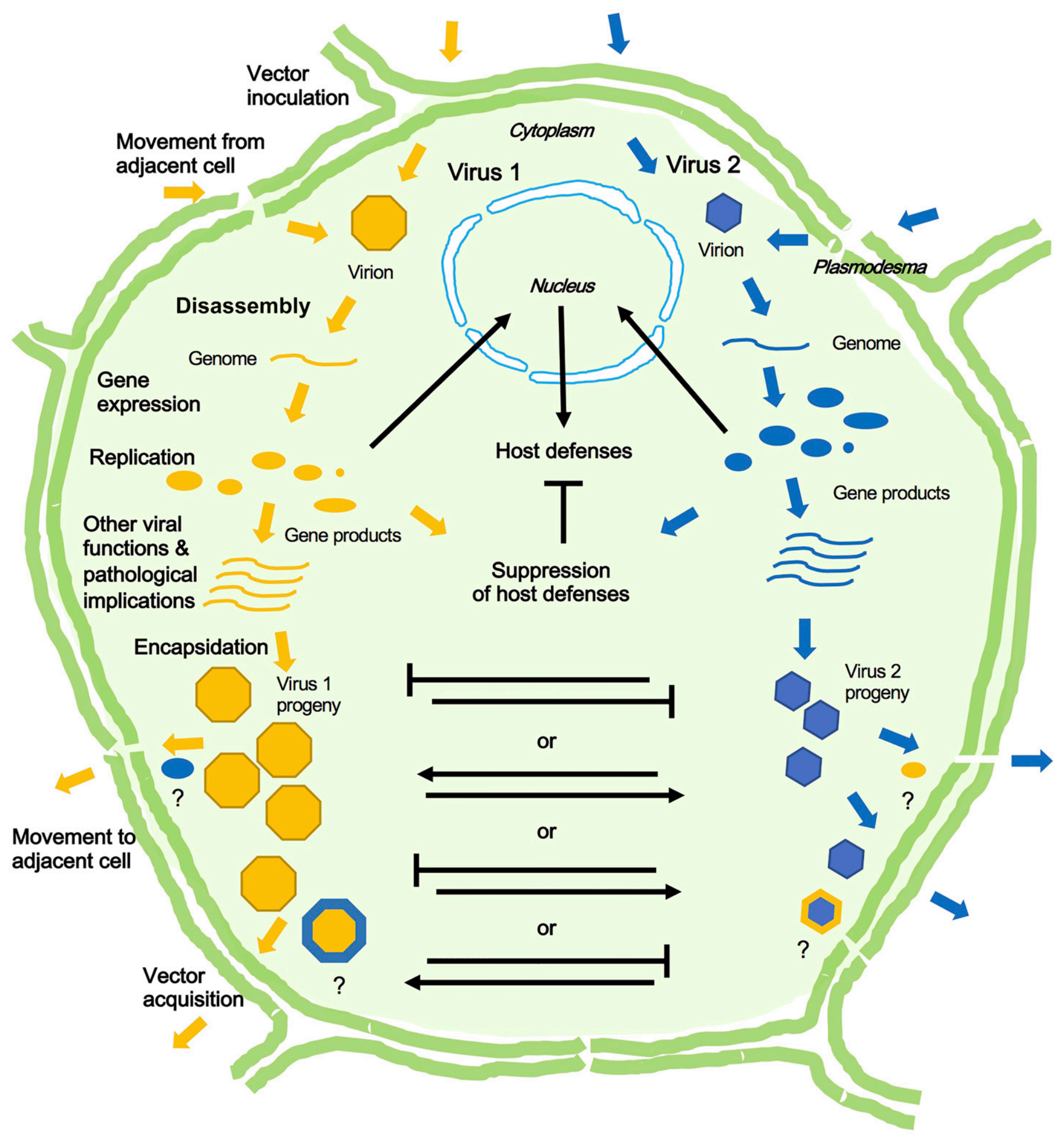

\section{FIGURE 2}

Schematic representation of interactions occurring at the cellular level during coinfection by two unrelated viruses (1 and 2) in a susceptible host plant. Cell entry and exit processes, either through the action of vector organisms (inoculation and acquisition) or through movement from and to adjacent cells (cell-to-cell transport through plasmodesmata, or invasion of distant tissues during long-distance transport), as well as essential intracellular viral processes (e.g., disassembly, gene expression, genome replication, and encapsidation of progeny) are represented by arrows of colors matching the individual viruses. The involvement of host factors and other processes is omitted for simplicity, as well as presumed differences in localization and timing of events. Outcomes of the positive and facilitative interactions are represented with arrows, whereas negative interactions are indicated by blockage symbols (T-shaped connectors); neutral effects are omitted for simplicity. Representative hypothetical examples of cross-assistance/ complementation of movement functions, or transcapsidations during vector transmission, are represented by question marks. See the text for further details. 
cassava mosaic virus, both members of the genus Begomovirus and leads to huge annual economic losses (Legg and Fauquet 2004). Many other cases are mentioned in Table 1. A frequent combination causing a synergistic interaction involves a potyvirus with different unrelated viruses, in most cases clearly favoring the second virus (Pruss et al. 1997), with the involvement of the potent RNA silencing suppressor helper-component proteinase (HC-Pro) of potyviruses (Valli et al. 2018). Interestingly, an exception is the SPVD mentioned in the introduction, in which the potyvirus partner SPFMV benefits from the presence of the crinivirus SPCSV (Karyeija et al. 2000); in this case, the RNA silencing function of SPFMV was shifted to a different gene product other than HC-Pro (Mingot et al. 2016; Untiveros et al. 2016).

There are some peculiarities in the interactions leading to conceptually clear synergisms that are not always easy to identify as such, because they affect traits beyond the measurable viral load. For instance, one kind of synergism could be the so-called helper dependence, in which one of the viruses involved is defective in one or more essential functions that in turn can be supplied by the other virus, the helper, acting as a provider or facilitator (Mascia and Gallitelli 2016). In an extreme example of this, one virus might become a sort of parasite of the other, such as in the interaction among Groundnut rosette virus (GRV), its satellite RNA (satRNA), and Groundnut rosette assistor virus (GRAV) that together cause groundnut rosette disease (GRD): GRV and its satRNA depend on the coat protein (CP) of GRAV to be encapsidated and transmitted by the aphid vector Aphis craccivora (Murant 1990). Another similar situation is the vectormediated transmission by complementation in trans, also referred to as heterologous complementation or transcomplementation. In certain viruses, such as potyviruses and caulimoviruses, there are nonstructural proteins called helper components that are needed for vector transmission, acting as specific molecular bridges between the virus particles and the vector (Pirone and Blanc 1996). It has been observed in mixed infections involving potyviruses and other unrelated viruses that these latter ones may benefit from the action of helper components by being transmitted. For instance, Potato aucuba mosaic virus (PAMV) is the only known member of the genus Potexvirus that can be transmitted by aphids as a result of transcomplementation when present in a mixed-infected plant together with a potyvirus (Kassanis 1961; Manoussopoulos 2001).
On the other hand, in the frame of an antagonistic interaction the presence of more than one virus is detrimental for at least one of them, for instance with a measurable decrease in the viral load. In general, it has been postulated that most of the described antagonism is attributable to interactions, direct or indirect, between proteins from the viruses involved in the mixed infection (DaPalma et al. 2010; Díaz-Muñoz 2019). Compared with synergistic interactions, there are fewer examples of antagonism, which is expected because attenuation instead of exacerbation is more likely to remain unnoticed. Furthermore, in a theoretical situation of synergism plus antagonism (as in the last column of the lower panel in Fig. 1), it is more likely that the outcome was described as synergistic for the enhanced virus simply because not enough attention was paid to the alleviated partner. As welldocumented examples, we can mention the suggested antagonism between isolates of Potato virus $X$ (PVX) and of Potato virus $Y$ (PVY) in tobacco (Ross 1950), as well as work in papaya with mixed infections between isolates of Papaya ringspot virus (PRSV) and of Papaya mosaic virus (PapMV) (Chávez-Calvillo et al. 2016). We can also mention the antagonism observed in tomato between isolates of Tomato torrado virus (ToTV) and of Pepino mosaic virus (PepMV), where the severity of ToTVinduced symptoms was unaffected but differences in virus accumulation were observed in mix-infected plants; the titer of ToTV slightly increased in the early phase of the infection, whereas that of PepMV was strongly reduced at all timepoints, including a pronounced decrease at later times. In this case, effects on the epidemiology of viruses have been reported (Gómez et al. 2009, 2010). As an additional case, antagonism was reported between two tobamoviruses, Hibiscus latent Singapore virus (HLSV) and Tobacco mosaic virus (TMV), in Nicotiana benthamiana plants; HLSV levels were decreased compared with a single infection, whereas TMV levels remained almost unaltered (Chen et al. 2012).

An interesting type of antagonistic interaction is crossprotection, also known as homologous interference or superinfection exclusion, which takes place when the presence of one virus prevents or interferes with a subsequent infection by another virus that is, generally, but not exclusively, homologous (Syller and Grupa 2016). In the context of agricultural activity, crossprotection can be very useful for biological control against viral diseases, mainly in cases where either no genetic resistance
FIGURE 3

Additional levels of interaction during viral mixed infections of plants. A schematic cross-section of a leaf (epidermis, parenchyma, and vasculature) is shown, together with the routes of hypothetical spread of infections by a virus capable of invading all tissues (virus 1, orange arrows) and another restricted to the vascular tissues (virus 2, blue arrows). Mixed infection might lead to interactions like those indicated by question marks: both facilitative and blocking outcomes of intracellular interactions (see Fig. 2) could influence dispersal of the viruses in the plant, and thus condition its

effects (see Fig. 1). Furthermore, the behavior and performance of the vectors responsible for transmission (here represented as different insect vectors for each virus) might also respond positively or negatively to manipulative strategies (see Fig. 1). Arrows and T-shaped connectors represent positive and negative cross-interactions that can take place between viruses during mixed infections inside the plant and in the possible effect of one virus on the vector of the other virus. See the text for further details.
Environment

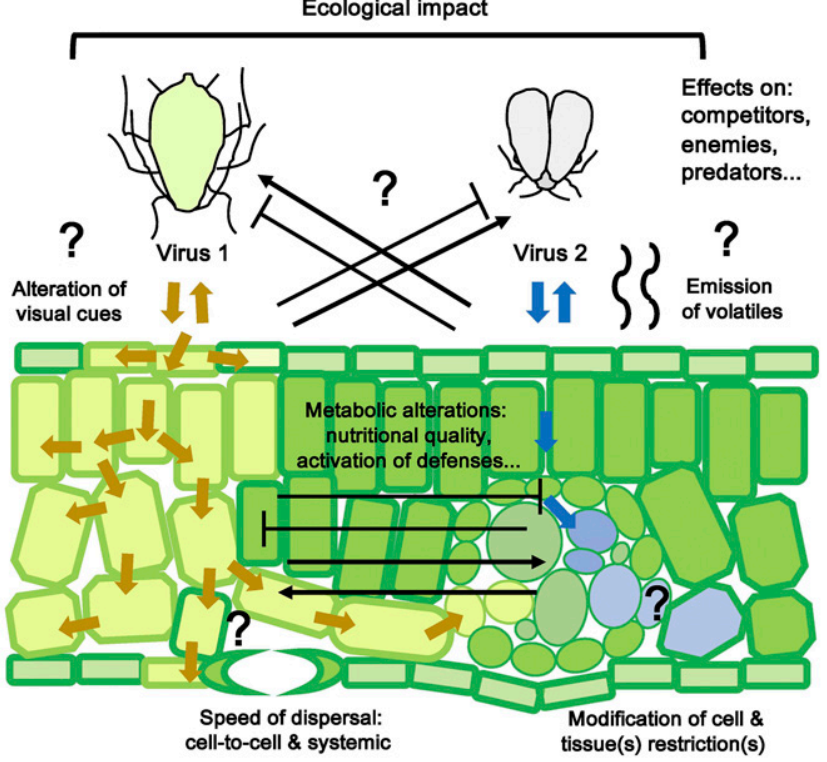


TABLE 1

Examples of mixed viral infections in plants caused by pairs of viruses

\begin{tabular}{|c|c|c|c|c|}
\hline Virus $1^{a}$ & Virus $2^{\mathrm{b}}$ & Host plants ${ }^{c}$ & Comments & References \\
\hline AbMV (Begomovirus) & $\begin{array}{l}\text { Tomato mosaic virus } \\
\text { (ToMV) (Tobamovirus) }\end{array}$ & $\begin{array}{l}\text { N. benthamiana and } \\
\text { tomato (Solanum } \\
\text { lycopersicum) }\end{array}$ & $\begin{array}{l}\text { Negative effect of ToMV on } \\
\text { AbMV accumulation and a } \\
\text { synergistic enhancement } \\
\text { in pathogenicity }\end{array}$ & $\begin{array}{l}\text { Pohl and Wege } \\
\text { (2007) }\end{array}$ \\
\hline $\begin{array}{l}\text { African cassava mosaic } \\
\text { virus (ACMV) (isolate } \\
\text { ACMV-CM) } \\
\text { (Begomovirus) }\end{array}$ & $\begin{array}{l}\text { East African cassava } \\
\text { mosaic Cameroon } \\
\text { virus (EACMCV) } \\
\text { (Begomovirus) }\end{array}$ & $\begin{array}{l}N . \text { benthamiana and } \\
\text { tobacco }(N . \text { tabacum) } \\
\text { protoplasts }\end{array}$ & $\begin{array}{l}\text { Synergism with an increase } \\
\text { in symptom severity and } \\
\text { viral accumulation of } \\
\text { both viruses. Post- } \\
\text { transcriptional gene } \\
\text { silencing (PTGS) involved } \\
\text { in the interaction }\end{array}$ & $\begin{array}{l}\text { Vanitharani et al. } \\
(2004)\end{array}$ \\
\hline $\begin{array}{l}\text { Bean pod mottle virus } \\
\text { (BPMV) (Comovirus) }\end{array}$ & $\begin{array}{l}\text { Soybean mosaic virus } \\
\text { (SMV) (Potyvirus) }\end{array}$ & Soybean (Glycine max) & $\begin{array}{l}\text { Synergism. Effects on } \\
\text { biochemical traits of the } \\
\text { plant and on behavior and } \\
\text { performance of vectors }\end{array}$ & $\begin{array}{l}\text { Lee and Ross } \\
\text { (1972) and } \\
\text { Peñaflor et al. } \\
\text { (2016) }\end{array}$ \\
\hline BPMV (Comovirus) & $\begin{array}{l}\text { Bean yellow mosaic } \\
\text { virus (BYMV) or } \\
\text { Peanut mottle virus } \\
\text { (PeMoV) (Potyvirus) }\end{array}$ & Soybean (G. max) & Neutralism & $\begin{array}{l}\text { Anjos et al. } \\
(1992)\end{array}$ \\
\hline BYMV (Potyvirus) & $\begin{array}{l}\text { A potyvirus strain of } \\
\text { uncertain taxonomical } \\
\text { status denominated } \\
\text { Pea mosaic virus } \\
\text { (Potyvirus) }\end{array}$ & Pea (Pisum sativum) & $\begin{array}{l}\text { A nonaphid-transmissible } \\
\text { isolate of BYMV that } \\
\text { depends on mixed } \\
\text { infection with the } \\
\text { postyvirus strain pea } \\
\text { mosaic potyvirus to be } \\
\text { transmitted }\end{array}$ & $\begin{array}{l}\text { Hobbs and } \\
\text { McLaughlin } \\
\text { (1990) }\end{array}$ \\
\hline $\begin{array}{l}\text { Cowpea chlorotic mottle } \\
\text { virus (CCMV) } \\
\text { (Bromovirus) }\end{array}$ & $\begin{array}{l}\text { SMV, PeMoV } \\
\text { (Potyvirus), or } \\
\text { Tobacco ringspot virus } \\
\text { (TRSV) (Nepovirus) }\end{array}$ & Soybean (G. max) & $\begin{array}{l}\text { Effect of mixed infections } \\
\text { on plant characteristics } \\
\text { and chemical } \\
\text { composition. No } \\
\text { synergism observed }\end{array}$ & $\begin{array}{l}\text { Demski and Jellu } \\
\text { (1975) }\end{array}$ \\
\hline CMV (Cucumovirus) & $\begin{array}{l}\text { Blackeye cowpea } \\
\text { mosaic potyvirus } \\
\text { (BICMV) (Potyvirus) }\end{array}$ & $\begin{array}{l}\text { Cowpea (Vigna } \\
\text { unguiculata), Cassia } \\
\text { obtusifolia, cucumber } \\
\text { (Cucumis sativus), } \\
\text { zucchini (Cucurbita } \\
\text { pepo), G. max, } \\
\text { N. tabacum, Phaseolus } \\
\text { lunatus, bean } \\
\text { (Phaseolus vulgaris) }\end{array}$ & $\begin{array}{l}\text { Synergism and cause of } \\
\text { cowpea stunt disease. } \\
\text { Can reduce yield of } \\
\text { cowpea in the } \\
\text { greenhouse. Aphids can } \\
\text { transmit both viruses } \\
\text { from mixed-infected } \\
\text { plants }\end{array}$ & $\begin{array}{l}\text { Pio-Ribeiro et al. } \\
\text { (1978) }\end{array}$ \\
\hline CMV (Cucumovirus) & BICMV (Potyvirus) & Cowpea (V. unguiculata) & $\begin{array}{l}\text { Synergism. Severe } \\
\text { symptoms might not be } \\
\text { only attributable to an } \\
\text { increase in CMV levels }\end{array}$ & $\begin{array}{l}\text { Anderson et al. } \\
\text { (1996) }\end{array}$ \\
\hline
\end{tabular}

(Continued on next page)

\footnotetext{
${ }^{a}$ Viruses are listed in alphabetical order with their acronym and include the taxonomic adscription (genus) in parentheses.

${ }^{b}$ When the bibliographical references include data for more than a pair of viruses, the second partner of every combination is mentioned but is separated with a comma.

${ }^{c}$ Common names and scientific names are used to identify hosts.
} 
mechanisms are known or they cannot be easily implemented. In such scenarios, avirulent or mild protecting viruses can be inoculated to crop plants to prevent aggressive viral infections in the field, acting as a kind of "vaccine" and reducing economic losses. Successful cases of cross-protection are the control of
Citrus tristeza virus, Zucchini yellow mosaic virus (ZYMV), and PRSV (Ziebell and Carr 2010).

An important factor that influences the outcome of a mixed infection is the moment at which the viruses arrive and infect the host. Coinfection is defined when the viruses simultaneously

\begin{tabular}{|c|c|c|c|c|}
\hline \multicolumn{5}{|c|}{$\begin{array}{c}\text { TABLE } 1 \\
\text { (Continued from previous page) }\end{array}$} \\
\hline Virus $1^{a}$ & Virus $2^{b}$ & Host plantsc & Comments & References \\
\hline CMV (Cucumovirus) & $\begin{array}{l}\text { Pepper mottle virus } \\
\text { (PepMoV) (Potyvirus) }\end{array}$ & $\begin{array}{l}\text { Pepper (Capsicum } \\
\text { annuum) }\end{array}$ & $\begin{array}{l}\text { Synergism. Detailed } \\
\text { evaluation of symptom } \\
\text { severity and statistical } \\
\text { proof of synergy }\end{array}$ & $\begin{array}{l}\text { Murphy and } \\
\text { Bowen } \\
\text { (2006) }\end{array}$ \\
\hline $\begin{array}{l}\text { CMV (Fny-CMV and } \\
\text { LS-CMV) } \\
\text { (Cucumovirus) }\end{array}$ & $\begin{array}{l}\text { Watermelon mosaic } \\
\text { virus (WMV) } \\
\text { (Potyvirus) }\end{array}$ & $\begin{array}{l}\text { Zucchini (Cucurbita } \\
\text { pepo) }\end{array}$ & $\begin{array}{l}\text { Synergism with a high } \\
\text { increase of CMV levels }\end{array}$ & $\begin{array}{l}\text { Wang et al. } \\
\text { (2002) }\end{array}$ \\
\hline $\begin{array}{l}\text { CMV (Fny-CMV and } \\
\text { LS-CMV) } \\
\text { (Cucumovirus) }\end{array}$ & $\begin{array}{l}\text { Zucchini yellow mosaic } \\
\text { virus (ZYMV) } \\
\text { (Potyvirus) }\end{array}$ & $\begin{array}{l}\text { Zucchini (Cucurbita } \\
\text { pepo), melon } \\
\text { (Cucumis melo) }\end{array}$ & $\begin{array}{l}\text { Strong synergistic } \\
\text { pathological responses }\end{array}$ & $\begin{array}{l}\text { Wang et al. } \\
\text { (2002) }\end{array}$ \\
\hline $\begin{array}{l}\text { CMV (impaired in long- } \\
\text { distance, strain } \\
\text { M-CMV) } \\
\text { (Cucumovirus) }\end{array}$ & $\begin{array}{l}\text { ZYMV (strains ZYMV-A } \\
\text { and ZYMV-AG) } \\
\text { (Potyvirus) }\end{array}$ & $\begin{array}{l}\text { Zucchini (Cucurbita } \\
\text { pepo) }\end{array}$ & $\begin{array}{l}\text { Synergism in pathology and } \\
\text { gain of long-distance } \\
\text { movement for M-CMV }\end{array}$ & $\begin{array}{l}\text { Choi et al. } \\
\text { (2002) }\end{array}$ \\
\hline $\begin{array}{l}\text { Lettuce infectious } \\
\text { yellows virus (LIYV) } \\
\text { (Crinivirus) }\end{array}$ & TuMV (Potyvirus) & N. benthamiana & $\begin{array}{l}\text { Synergistic interaction with } \\
\text { enhanced accumulation } \\
\text { of LIYV, mediated by } \\
\text { the entire TuMV or only } \\
\text { the TuMV P1/helper- } \\
\text { component proteinase } \\
\text { (HC-Pro) sequence }\end{array}$ & $\begin{array}{l}\text { Wang et al. } \\
(2009 a, b)\end{array}$ \\
\hline $\begin{array}{l}\text { Maize chlorotic mottle } \\
\text { virus (MCMV) } \\
\text { (Machlomovirus) }\end{array}$ & $\begin{array}{l}\text { Maize dwarf mosaic } \\
\text { virus A (MDMV-A) } \\
\text { (Potyvirus) }\end{array}$ & $\begin{array}{l}\text { Maize (Zea mays), } \\
\text { sorghum (Sorghum } \\
\text { vulgare), wheat } \\
\text { (Triticum aestivum) }\end{array}$ & $\begin{array}{l}\text { Synergism and cause of } \\
\text { corn lethal necrosis } \\
\text { disease (CLND). Field } \\
\text { survey in Kansas, U.S.A. }\end{array}$ & $\begin{array}{l}\text { Uyemoto et al. } \\
\text { (1980) }\end{array}$ \\
\hline $\begin{array}{l}\text { MCMV } \\
\text { (Machlomovirus) }\end{array}$ & WSMV (Tritimovirus) & Maize (Z. mays) & $\begin{array}{l}\text { Synergism and cause of } \\
\text { corn lethal necrosis (now } \\
\text { called maize lethal } \\
\text { necrosis [MLN]). WSMV } \\
\text { infections were enhanced } \\
\text { by MCMV and more } \\
\text { pronounced at higher } \\
\text { temperatures }\end{array}$ & Scheets (1998) \\
\hline $\begin{array}{l}\text { MCMV } \\
\text { (Machlomovirus) }\end{array}$ & $\begin{array}{l}\text { SCMV, MDMV, or } \\
\text { Johnsongrass mosaic } \\
\text { virus (JGMV) (all } \\
\text { Potyvirus) }\end{array}$ & Maize (Z. mays) & $\begin{array}{l}\text { Synergism caused by } \\
\text { coinfection of MCMV } \\
\text { with any one of the } \\
\text { indicated Potyvirus } \\
\text { viruses. The resulting } \\
\text { disease is known as MLN } \\
\text { and causes high } \\
\text { economic losses }\end{array}$ & $\begin{array}{l}\text { Stewart et al. } \\
(2017)\end{array}$ \\
\hline
\end{tabular}

(Continued on next page) 
infect the host, arriving at roughly the same time, whereas superinfection refers to mixed infections where the viruses arrive at different moments (Saldaña et al. 2003). In nature, the occurrence of each one depends on the viral density and the number of healthy hosts available during the epidemic episode: at the beginning, with low viral densities and a high number of uninfected plants, the occurrence of coinfections can be favored; later, as the diseases spread and the number of healthy host plants

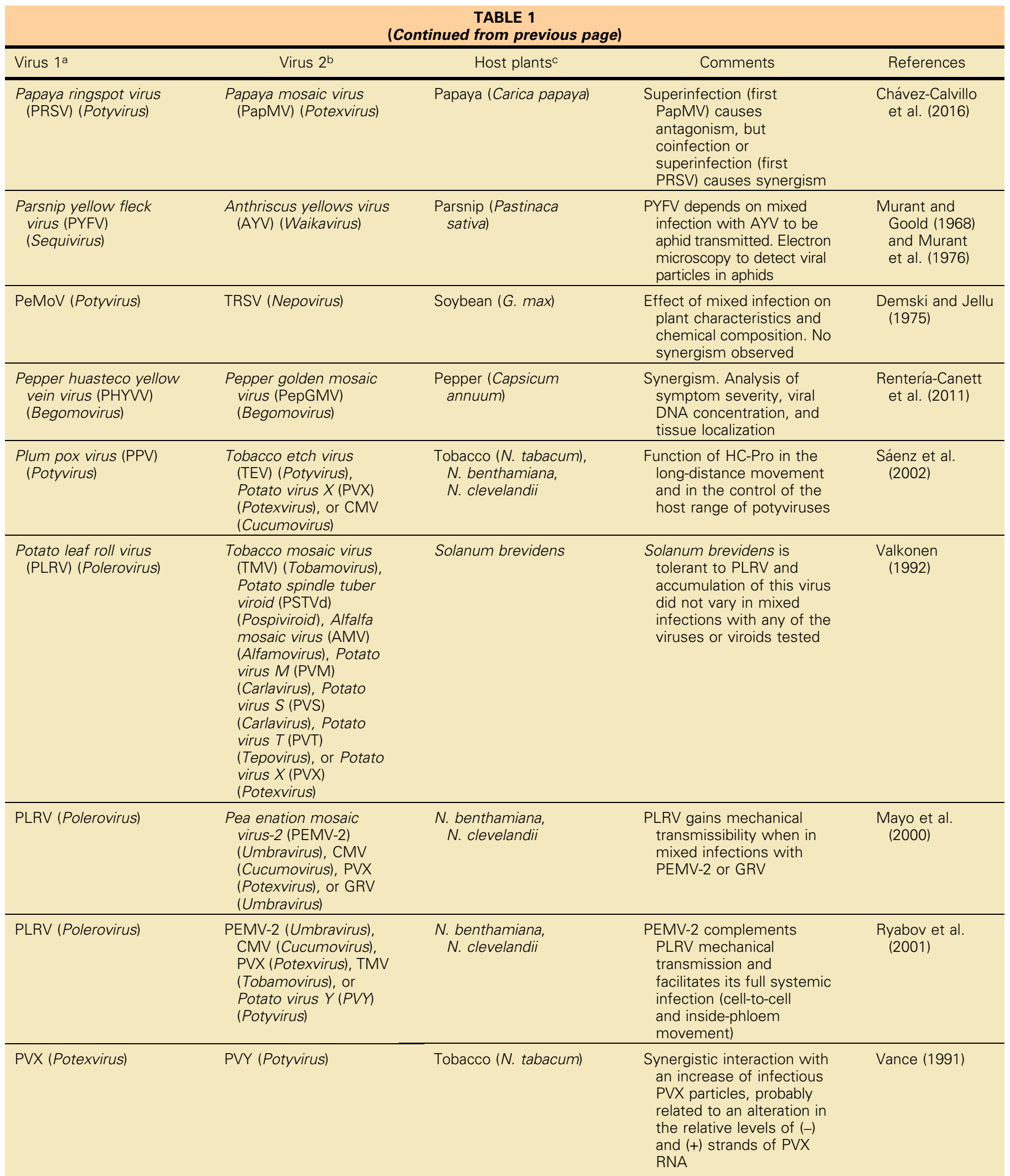


decrease gradually, while the viral density increases, superinfections become more frequent (Miralles et al. 2001; Saldaña et al. 2003). The moment of infection might also influence virus evolution; for instance, virus fitness might increase in coinfec- tions and not in superinfections (Miralles et al. 2001). In addition, the outcome of superinfections may be dramatically influenced by aspects such as the order of infection of the viruses involved and the timeframe between the infections; for both coinfections

\begin{tabular}{|c|c|c|c|c|}
\hline \multicolumn{5}{|c|}{$\begin{array}{c}\text { TABLE } 1 \\
\text { (Continued from previous page) }\end{array}$} \\
\hline Virus $1^{a}$ & Virus $2^{b}$ & Host plants ${ }^{c}$ & Comments & References \\
\hline PVX (Potexvirus) & $\begin{array}{l}\text { PVY (N-Wi strain) } \\
\text { (Potyvirus) }\end{array}$ & $\begin{array}{l}\text { N. benthamiana, } \\
\text { tobacco ( } N \text {. tabacum) }\end{array}$ & $\begin{array}{l}\text { Synergism. Quantification } \\
\text { of symptom expression } \\
\text { and levels of coat proteins } \\
\text { and suppressors of } \\
\text { silencing under different } \\
\text { temperature conditions } \\
\text { and during co- or } \\
\text { superinfection }\end{array}$ & $\begin{array}{l}\text { Senanayake and } \\
\text { Mandal (2014) }\end{array}$ \\
\hline PVX (Potexvirus) & $\begin{array}{l}\text { Potato virus A (PVA) } \\
\text { (Potyvirus) }\end{array}$ & N. benthamiana & $\begin{array}{l}\text { HC-Pro from PVA mediates } \\
\text { reductions on methionine } \\
\text { and glutathione and has a } \\
\text { crucial role in the } \\
\text { synergism observed }\end{array}$ & De et al. (2018) \\
\hline PVY (Potyvirus) & CMV (Cucumovirus) & $\begin{array}{l}\text { Tomato (Solanum } \\
\text { lycopersicum) }\end{array}$ & $\begin{array}{l}\text { Increase of both PVY and } \\
\text { CMV levels. Differences } \\
\text { with the same mixed } \\
\text { infection in tobacco and } \\
\text { cucumber }\end{array}$ & $\begin{array}{l}\text { Mascia et al. } \\
\text { (2010) }\end{array}$ \\
\hline PVY (Potyvirus) & TEV (Potyvirus) & $\begin{array}{l}\text { Pepper (Capsicum } \\
\text { annuum) }\end{array}$ & $\begin{array}{l}\text { A nonaphid-transmissible } \\
\text { strain of TEV depends on } \\
\text { mixed infection with PVY } \\
\text { to be aphid transmitted }\end{array}$ & Simons (1976) \\
\hline PVY (Potyvirus) & $\begin{array}{l}\text { TMV (Tobamovirus), } \\
\text { PSTVd (Pospiviroid), } \\
\text { AMV (Alfamovirus), } \\
\text { PVM (Carlavirus), PVS } \\
\text { (Carlavirus), PVT } \\
\text { (Tepovirus), or PVX } \\
\text { (Potexvirus) }\end{array}$ & Solanum brevidens & $\begin{array}{l}\text { Accumulation of PVY in } \\
\text { mixed-infected plants } \\
\text { with TMV and PSTVd } \\
\text { increased up to 1,000- } \\
\text { fold, whereas no changes } \\
\text { were observed in } \\
\text { coinfections with the other } \\
\text { viruses tested. Solanum } \\
\text { brevidens is tolerant to PVY } \\
\text { and PVX, which explains } \\
\text { differences with other } \\
\text { cases between PVX and } \\
\text { PVY (usually synergistic) }\end{array}$ & $\begin{array}{l}\text { Valkonen } \\
\text { (1992) }\end{array}$ \\
\hline PVY (Potyvirus) & PLRV (Polerovirus) & $\begin{array}{l}\text { Potato (Solanum } \\
\text { tuberosum) }\end{array}$ & $\begin{array}{l}\text { Synergism with more } \\
\text { severe symptoms. Effect } \\
\text { of the mixed infection } \\
\text { on the fecundity and } \\
\text { preference of two aphid } \\
\text { vectors of PVY and PLRV }\end{array}$ & $\begin{array}{l}\text { Srinivasan and } \\
\text { Alvarez } \\
\text { (2007) }\end{array}$ \\
\hline
\end{tabular}

(Continued on next page) 
TABLE 1

(Continued from previous page)

\begin{tabular}{|c|c|c|c|c|}
\hline Virus $1^{a}$ & Virus $2^{b}$ & Host plantsc & Comments & References \\
\hline $\begin{array}{l}\text { Southern rice black- } \\
\text { streaked dwarf virus } \\
\text { (SRBSDV) (Fijivirus) }\end{array}$ & $\begin{array}{l}\text { Rice ragged stunt virus } \\
\text { (RRSV) (Oryzavirus) }\end{array}$ & Rice (Oryza sativa) & $\begin{array}{l}\text { Synergism. Increase in } \\
\text { replication and movement } \\
\text { of viruses and inhibition of } \\
\text { host immunity. Alteration } \\
\text { on vector selection } \\
\text { preferences tending to } \\
\text { enhance mixed infection }\end{array}$ & $\begin{array}{l}\text { Li et al. (2017) } \\
\text { and Wang et al. } \\
\text { (2014) }\end{array}$ \\
\hline SMV (Potyvirus) & $\begin{array}{l}\text { TRSV (Nepovirus) or } \\
\text { PeMoV (Potyvirus) }\end{array}$ & Soybean (G. max) & $\begin{array}{l}\text { Effect of mixed infections } \\
\text { on plant characteristics } \\
\text { and chemical } \\
\text { composition. No } \\
\text { synergism observed }\end{array}$ & $\begin{array}{l}\text { Demski and Jellu } \\
\text { (1975) }\end{array}$ \\
\hline SMV (Potyvirus) & $\begin{array}{l}\text { Cowpea mosaic virus } \\
\text { (CPMV) (Comovirus) }\end{array}$ & Soybean (G. max) & $\begin{array}{l}\text { Synergism with increase of } \\
\text { CPMV. Localization by } \\
\text { electron microscopy }\end{array}$ & $\begin{array}{l}\text { Anjos et al. } \\
\text { (1992) }\end{array}$ \\
\hline $\begin{array}{l}\text { Strawberry pallidosis- } \\
\text { associated virus } \\
\text { (SPaV) (Crinivirus) }\end{array}$ & $\begin{array}{l}\text { Beet pseudo-yellows } \\
\text { virus (BPYV) } \\
\text { (Crinivirus) }\end{array}$ & $\begin{array}{l}\text { Strawberry } \\
\quad(\text { Fragaria } \times \text { ananassa })\end{array}$ & $\begin{array}{l}\text { Causal agents of strawberry } \\
\text { pallidosis disease. } \\
\text { Detection in field surveys in } \\
\text { North America and Peru }\end{array}$ & $\begin{array}{l}\text { Tzanetakis et al. } \\
\text { (2006) and } \\
\text { Wintermantel } \\
\text { et al. (2006) } \\
\end{array}$ \\
\hline $\begin{array}{l}\text { Sweet potato chlorotic } \\
\text { stunt virus (SPCSV) } \\
\text { (Crinivirus) }\end{array}$ & $\begin{array}{l}\text { Sweet potato feathery } \\
\text { mottle virus (SPFMV) } \\
\text { (Potyvirus) }\end{array}$ & $\begin{array}{l}\text { Sweet potato } \\
\text { (/pomoea batatas) }\end{array}$ & $\begin{array}{l}\text { Together they cause the } \\
\text { sweet potato virus } \\
\text { disease, a synergistic } \\
\text { interaction with a } 600 \text {-fold } \\
\text { increase of SPFMV and } \\
\text { severe symptoms }\end{array}$ & $\begin{array}{l}\text { Karyeija et al. } \\
(2000)\end{array}$ \\
\hline TMV (Tobamovirus) & $\begin{array}{l}\text { Hibiscus latent } \\
\text { Singapore virus } \\
\text { (HLSV) (Tobamovirus) }\end{array}$ & N. benthamiana & $\begin{array}{l}\text { Evolutionary game theory } \\
\text { to model the coinfection } \\
\text { between TMV and HLSV } \\
\text { and validation by } \\
\text { quantitative RT-PCR }\end{array}$ & $\begin{array}{l}\text { Chen et al. } \\
(2012)\end{array}$ \\
\hline $\begin{array}{l}\text { Tomato chlorosis virus } \\
\text { (ToCV) (Crinivirus) }\end{array}$ & $\begin{array}{l}\text { Tomato spotted wilt } \\
\text { virus (TSWV) } \\
\text { (Tospovirus) }\end{array}$ & $\begin{array}{l}\text { Tomato (Solanum } \\
\text { lycopersicum) }\end{array}$ & $\begin{array}{l}\text { Synergism increases ToCV } \\
\text { while TSWV does not } \\
\text { change. Breakdown of } \\
\text { resistance against TSWV } \\
\text { in plants preinfected with } \\
\text { ToCV, contrarily to } \\
\text { coinfection }\end{array}$ & $\begin{array}{l}\text { García-Cano et al. } \\
\text { (2006) }\end{array}$ \\
\hline ToCV (Crinivirus) & $\begin{array}{l}\text { Tomato infectious } \\
\text { chlorosis virus (TICV) } \\
\text { (Crinivirus) }\end{array}$ & $\begin{array}{l}\text { Physalis wrightii, } \\
\text { N. benthamiana }\end{array}$ & $\begin{array}{l}\text { Effects of coinfection in } \\
\text { virus accumulation and } \\
\text { transmission efficiency } \\
\text { are host specific }\end{array}$ & $\begin{array}{l}\text { Wintermantel } \\
\text { et al. (2008) }\end{array}$ \\
\hline
\end{tabular}


and superinfections, differences in the capacity of viruses to invade or not invade certain tissues have been observed. Next, a series of examples are provided to illustrate the different outcomes that can result.

In the previously mentioned work in papaya, the outcome of the mixed infection was different when the plant was infected first with PapMV and then with PRSV, causing the antagonism mentioned; if either the order was reversed or the viruses arrived simultaneously, the result was synergism (Chávez-Calvillo et al. 2016). Similarly, the example given above of an antagonistic interaction between HLSV and TMV occurred in the frame of a coinfection, but the authors mentioned that the presence of HLSV in a superinfection protected the host against a late arrival of TMV, thus acting in practical terms as a cross-protection event (Chen et al. 2012). Another example of conditional outcome derives from one of the first synergisms described: tobacco plants infected with isolates of PVY and PVX (Damirdagh and Ross 1967; Goodman and Ross 1974; Smith 1931; Vance 1991). When PVX was inoculated on tobacco previously infected with PVY, the levels of accumulation of PVX increased considerably compared with the single-infected control. However, this synergism was compromised if the time between the infections with the two viruses was $>24 \mathrm{~h}$; it was later demonstrated that the silencing suppressor of the potyvirus PVY (HC-Pro) was one of the factors involved in the outcome of the synergism (González-Jara et al. 2005). As a final example of the different relationships occurring between viruses in mixed infections, we can cite work in tomato plants involving mixed infections of Tomato chlorosis virus (ToCV) and Tomato spotted wilt virus (TSWV) that resulted in a synergism that can even end with the death of susceptible plants. In those plants, there was a high increase in ToCV accumulation, whereas TSWV levels remained unaltered. Coinfection of TSWV-resistant plants with ToCV and TSWV did not alter the resistance behavior of the plants; however, and most interestingly, when the resistant plants were challenged in a superinfection with ToCV arriving before TSWV, the resistance was lost. This observation suggested that ToCV might need a certain amount of time to affect the defense response in the resistant plants, such as requiring enough time to express some proteins acting as suppressors of RNA silencing, or to reach a certain accumulation level (García-Cano et al. 2006). However, interference with the plant defense mechanisms by viral proteins is likely not the only component that determines whether an interaction will be synergic or antagonistic: some proteins may facilitate the replication, intercellular movement, and/or the within-host spread of the other virus (Elena et al. 2014).

Mixed infections by the same combination of viruses but in different host plants may also lead to different outcomes in virus accumulation levels, host response, and transmission by vector organisms, for example. We will consider these aspects in different sections, but it is relevant to stress that virus-virus interactions are highly dependent on the biological environment (i.e., the

TABLE 1

(Continued from previous page)

\begin{tabular}{|c|c|c|c|c|}
\hline Virus $1^{\mathrm{a}}$ & Virus $2^{b}$ & Host plants ${ }^{c}$ & Comments & References \\
\hline $\begin{array}{l}\text { Tomato leaf curl New } \\
\text { Delhi virus (ToLCNDV) } \\
\text { (Begomovirus) }\end{array}$ & $\begin{array}{l}\text { Tomato leaf curl } \\
\text { Palampur virus } \\
\text { (ToLCPalV) } \\
\text { (Begomovirus) }\end{array}$ & $\begin{array}{l}\text { Tomato (Solanum } \\
\text { lycopersicum), } \\
\text { cucumber (Cucumis } \\
\text { sativus) }\end{array}$ & $\begin{array}{l}\text { Genetic reassortment and } \\
\text { heteroencapsidation. } \\
\text { Whitefly transmission of } \\
\text { pseudorecombinants }\end{array}$ & $\begin{array}{l}\text { Kanakala et al. } \\
(2013)\end{array}$ \\
\hline $\begin{array}{l}\text { Tomato rugose mosaic } \\
\text { virus (ToRMV) } \\
\text { (Begomovirus) }\end{array}$ & $\begin{array}{l}\text { Tomato yellow spot } \\
\text { virus (ToYSV) } \\
\text { (Begomovirus) }\end{array}$ & $\begin{array}{l}\text { N. benthamiana, tomato } \\
\text { (Solanum } \\
\text { lycopersicum) }\end{array}$ & $\begin{array}{l}\text { ToYSV induces a change in } \\
\text { tissue tropism of ToRMV } \\
\text { (exits phloem). Both } \\
\text { positive (synergism) and } \\
\text { negative (interference) } \\
\text { interactions are observed } \\
\text { depending on the } \\
\text { infection stage }\end{array}$ & $\begin{array}{l}\text { Alves-Júnior } \\
\text { et al. (2009) }\end{array}$ \\
\hline WSMV (Tritimovirus) & $\begin{array}{l}\text { Triticum mosaic virus } \\
\text { (TriMV) (Poacevirus) }\end{array}$ & Wheat ( $T$. aestivum) & $\begin{array}{l}\text { Cultivar-specific synergism } \\
\text { and influence of different } \\
\text { temperatures. } \\
\text { Determination of different } \\
\text { physiological parameters. } \\
\text { Impact on endogenous } \\
\text { and viral small RNA } \\
\text { profiles }\end{array}$ & $\begin{array}{l}\text { Byamukama } \\
\text { et al. (2012) } \\
\text { and Tatineni } \\
\text { et al. (2010, } \\
\text { 2014) }\end{array}$ \\
\hline ZYMV (Potyvirus) & CMV (Cucumovirus) & $\begin{array}{l}\text { Zucchini (Cucurbita } \\
\text { pepo) }\end{array}$ & $\begin{array}{l}\text { Synergism with increase of } \\
\text { CMV levels }\end{array}$ & Fattouh (2003) \\
\hline
\end{tabular}


common host) where they are present together. As an example, we can cite a mixed infection between two criniviruses, ToCV and Tomato infectious chlorosis virus (TICV), in two different host plants: Physalis wrightii and $N$. benthamiana (Wintermantel et al. 2008). Compared with single infections, the titer of both viruses decreased in mixed infections of $P$. wrightii, whereas TICV titers increased and ToCV decreased in $N$. benthamiana. Vector transmission efficiencies by Trialeurodes vaporariorum were directly correlated with the accumulation levels of both viruses, with more transmission of TICV from mixed-infected plants (this case fits in the proposed effect of the last column in Fig. 1). Even more interestingly, vector T. abutilonea was able to transmit TICV from mixed-infected plants, even if it was described as a nonvector for this virus alone (Duffus et al. 1996). This suggests that a complementation for transmission might have taken place, with ToCV providing one or more factors necessary for the T. abutiloneaTICV association and subsequent transmission in a process independent of host factors, as the virus was transmitted from both hosts (Wintermantel et al. 2008).

The interaction between viruses inside a host cell (as represented schematically in Fig. 2) can be highly influenced by the multiplicity of infection (MOI), which indicates the number of viral genomes present in the same cell (Gutiérrez et al. 2010). There are some indications that the MOI is controlled by virusencoded functions, such as the suppression of RNA silencing mechanisms (Donaire et al. 2016). In mixed infections of $N$. benthamiana with two genotypes of TMV, the MOI was higher at initial stages and then changed (González-Jara et al. 2009). Determining the values of the MOI and how they are regulated can help to decipher the relationships between dynamics of virus populations and the control of genome copy numbers (Gutiérrez et al. 2012). Beyond the cellular level but closely related to this topic is the tissue tropism or the specificity of each virus to infect only some cell types or tissues (Mascia and Gallitelli 2016). During infection of a host plant, viruses might be found in different cells, from all types to only those found in vascular tissues, or exhibit restrictions to enter meristems or invade seeds. In the case of mixed viral infections, we could expect modifications and changes in host responses that might condition the pathology of the viruses involved. These responses, for instance, might alter the tissue tropism, a phenomenon observed mainly in phloem restricted viruses (Mascia and Gallitelli 2016). In single infections of $N$. benthamiana plants, Tomato yellow spot virus (ToYSV) localizes in mesophyll cells, whereas Tomato rugose mosaic virus (ToRMV) is restricted to the phloem. However, when the plant is infected by both ToYSV and ToRMV, the localization of ToRMV changes and the virus becomes able to invade mesophyll cells as well (Alves-Júnior et al. 2009). Also in $N$. benthamiana, mixed infections between isolates of the potyvirus Potato virus A (PVA) and of the luteovirus Potato leaf roll virus (PLRV) allow the latter virus to infect different cell types in leaves, whereas it is restricted to the phloem in single infection. A possible explanation would be that movement proteins from PVA could complement movement deficiencies of PLRV, in a mechanism independent of the RNA silencing suppression function of HC-Pro (Savenkov and Valkonen 2001). Similarly, in $N$. clevelandii and $N$. benthamiana plants infected with both PLRV and the umbravirus Pea enation mosaic virus-2 (PEMV-2), PLRV gained the capacity to be mechanically transmitted because it could be located in mesophyll cells. Again, a modification in the cell-to-cell movement and the interference with the host RNA silencing mechanisms by PEMV-2 may explain this observation (Ryabov et al. 2001). Additional examples of similar outcomes are mixed infection by the begomovirus Abutilon mosaic virus (AbMV) and either the potyvirus Cowpea aphid-borne mosaic virus or the tombusvirus Artichoke mottled crinkle virus, which occasionally provoked the localization of AbMV in tissues other than the phloem
(Sardo et al. 2011), and the case of a movement-deficient strain of Cucumber mosaic virus (CMV) in zucchini squash that assisted in systemic spread by coinfection with a strain of the potyvirus ZYMV (Choi et al. 2002).

Besides these modifications in tissue tropism and virus distribution within the host, in some cases the mixed viral infection can even alter the host range. An example is the case of two sobemoviruses, Southern cowpea mosaic virus (SCPMV) and Southern bean mosaic virus (SBMV). SCPMV can infect cowpea (Vigna unguiculata) but not common bean (Phaseolus vulgaris), whereas SBMV can infect common bean but not cowpea. Even if the genomic RNA of SCPMV can replicate in bean cells, it cannot assembly viral particles. However, in coinfection with SBMV, it was observed that SCPMV accumulated in an encapsidated form in both inoculated and systemic bean leaves, suggesting a phenomenon of heterologous encapsidation or genome masking. Nevertheless, when the reciprocal experiment was done, the authors observed that SCPMV did not complement the host range restriction of SBMV in cowpea. Thus, in practice, the presence of SBMV modified the host range of SCPMV, allowing it to systemically infect bean, but SCPMV did not complement the host range restriction of SBMV, as it was unable to systemically infect cowpea (Hacker and Fowler 2000).

\section{IMPACT ON VECTORS}

Vectors are key players in many virus infection cycles, as a majority of plant viruses rely on them for dispersion. The virus transmission process by a vector organism involves finding the infected plant, acquisition (often through probing or feeding, as in the case of some phytophagous vectors), transport, and finally inoculation or delivery of virus to a new host plant. Vectors are the mobile partners in a plant-virus-plant interaction leading to dispersal of infection. Thus, the preferences of the vectors for one plant or another can condition the virus spread process. The importance of mixed viral infections in aphid transmission of plant viruses was reported previously in a review article rich in examples (Rochow 1972), addressing points such as the behavior of vectors or even recombination and transcapsidation events (these concepts are discussed in more detail in the previous section). All of these key concepts might have an impact on virus evolution.

Some works have also shown that vector behavior and/or physiology can be influenced by changes in the plant induced by viruses, which can in turn condition the spread and epidemiology of the viruses (Bak et al. 2017; Bosque-Pérez and Eigenbrode 2011). Therefore, in the case of mixed infections, the possibility of manipulative strategies must be considered. For instance, a surprising example of vector manipulation by viruses was described in rice plants and reflects the relationships of two reoviruses, Southern rice black-streaked dwarf virus (SRBSDV) and Rice ragged stunt virus (RRSV), with their insect vectors: the white-backed planthopper (WBPH; Sogatella furcifera) transmits SRBSDV, whereas the brown planthopper (BPH; Nilaparvata lugens) transmits RRSV (Wang et al. 2014). Preference assays using a Y-shape olfactometerbased device demonstrated that plants infected with SRBSDV modified the behavior not only of its vector WBPH but also of the nonvector BPH. Virus-free WBPHs were more attracted to infected plants than viruliferous insects, and viruliferous insects were more attracted to healthy plants than to infected ones: this result is consistent with manipulation of the vector to increase virus spread through virusinduced host modifications. Interestingly, the preference assays with BPHs, a nonvector of SRBSDV, showed only preference of rice plants infected with SRBSDV over a healthy plant, when they were viruliferous for RRSV, therefore favoring the occurrence of mixed infections. Further experiments are needed to elucidate the mechanisms involved in this behavior and to explain why viruses may manipulate host selection in order to favor the existence of mixed infections. 
The apparent manipulation of the vector by the virus often triggers an increase in transmission rates and consequently in virus spread, which ensures the existence of the virus species in the long term. In other words, virus acquisition will be increased by vector attraction to infected plants, and transmission will be improved by attraction to healthy plants where the virus can be inoculated. This concept is known as the vector manipulation hypothesis, and it was proposed to explain the different approaches employed by the pathogen to enhance its dissemination (Ingwell et al. 2012). The virus may directly influence the vector and modify its behavior, mainly in viruses that are transmitted in a persistent way while the virus is inside the body of the vector, as in the case of the thrip Frankliniella occidentalis (Pergande) whose feeding behavior is altered when infected by TSWV: infected males feed more than uninfected ones, thus increasing the possibility of virus inoculation (Stafford et al. 2011). This proposed general concept is still awaiting further studies to verify how common it is, and it will be especially interesting to measure transmission efficiencies and vector behavior parameters in mixed infections. For instance, a recent research effort in our laboratory incorporated measurements of aphid feeding behavior through electrical penetration graphs, finding that a particular subphase related to virus acquisition was prolonged by aphids feeding on melon plants coinfected by the potyvirus Watermelon mosaic virus (WMV) and the crinivirus Cucurbit yellow stunting disorder virus (CYSDV) compared with single-infected controls. Interestingly, this behavior might compensate a reduction in WMV load, thus ensuring efficient transmission of the potyvirus (Domingo-Calap et al. 2019).

Viruses may also indirectly influence vectors as a result of modifications in the host infected plant that will have an impact on the vector (Dietzgen et al. 2016). Manipulations exerted by viruses often result in a positive or neutral effect on transmission by vectors, and they are similar between different viruses depending on their mode of transmission (described in more detail in the next section) (Mauck et al. 2012). For example, we can cite the mixed infection of PVY and PLRV in potato plants that altered the performance of their most effective vectors, the aphids Myzus persicae and Macrosiphum euphorbiae. For both vectors, fecundity increased in mixed-infected potato plants, as did their preference for those plants (Srinivasan and Alvarez 2007). According to Srinivasan and Alvarez (2007), this behavior could be explained, at least in part, by an increase in sugars and amino acids in the phloem as a result of an inhibited phloem transport in mixed-infected compared with single-infected plants. In addition, it is likely that both viruses, when together, somehow manipulate the plant to make it more attractive to insects by visual and olfactory clues. Because mixed infections of PVY and PLRV are quite frequent in potato plants, the quality of hosts and the behavior of vectors during this interaction could have important epidemiological repercussions (Chatzivassiliou et al. 2008). Another example of this kind of multiple-level interaction involving vectors is provided by the above-mentioned mixed infection of WMV and CYSDV in melon. Our work showed a late time-recovery phenotype of the mixed-infected plants after a first onset of strong synergistic damage, resulting in a better condition and development and thus in more foliage surface available for acquisition of the viruses by vectors (Domingo-Calap et al. 2019).

An interesting feature related to mixed infections is that some viruses gain the ability to be transmitted by vectors that are not their natural vectors when they are infecting a susceptible plant alone. As we mentioned previously, the case of PAMV showed that a virus belonging to a taxonomic group (potexviruses) characterized by only contact dissemination can acquire an efficient vectormediated transmissibility during mixed infection with a potyvirus. The key molecular feature here was the presence of a conserved DAG motif, typical of potyviruses, in the potexvirus, as demon- strated in an elegant work through mutagenesis of the PVX CP to engineer the same aphid-transmissibility feature (Baulcombe et al. 1993).

Acquisition of new vector capacities was seen also in mixed infections by viruses from the family Luteoviridae, or in coinfections of unrelated viruses with a luteovirus. The general phenomenon can be named genomic masking or transcapsidation, and basically consists of a viral genome being encapsidated by the capsids of another virus present at the same time in the plant, generating a sort of chimeric new entity with shared properties (represented in Fig. 2 by orange and blue or blue and orange virus particles). Examples of this were observed in mixed-infected plants in which a virus gained transmissibility by different species of vectors. For instance, the aphid Sitobion avenae is a good vector of the MAV strain of the luteovirus Barley yellow dwarf virus (BYDV-MAV) in single infections, whereas the aphid Rhopalosiphon padi specifically transmits the RPV strain of the polerovirus Cereal yellow dwarf virus (CYDV-RPV). However, in plants infected by both viruses, BYDV-MAV also became transmissible by $R$. padi because the RNA of BYDV-MAV was encapsidated inside CYDV-RPV capsids, which conferred the transmissibility by $R$. padi (Creamer and Falk 1990; Rochow 1970). Similar results were described in oat and wheat infected by two strains of BYDV (BYDV-MAV and BYDV-PAV), where alterations in transmission specificity and synergism in symptoms were observed in addition to transcapsidation (Baltenberger et al. 1987; Creamer and Falk 1990).

The transcapsidation phenomenon is not restricted to luteoviruses and was also observed in viruses of the genus Umbravirus and some luteovirus-associated RNAs (specific subviral RNA replicons) that do not encode a CP. Their aphid-transmission capacity is absolutely dependent on transcapsidation with other coinfecting luteovirus (Casteel and Falk 2016; Syller 2000).

It is worth mentioning here a related situation known as heteroencapsidation, where a virus genome can partially acquire the properties of the particles of another virus through heterologous encapsidation. For instance, electron microscopy was used to demonstrate that an aphid nontransmissible isolate of the potyvirus ZYMV can produce heteroencapsidated particles in mixed infection with the potyvirus PRSV and thus be efficiently transmitted by aphids (Bourdin and Lecoq 1991). Other welldocumented examples involve whitefly-transmitted begomovirus from the family Geminiviridae, where the frequent recombinations that occur during mixed infections are one of the main sources of variability in this genus. To cite one case of heteroencapsidation, whitefly transmission of pseudorecombinants was demonstrated in a mixed infection between two bipartite viruses, Tomato leaf curl Palampur virus and Tomato leaf curl New Delhi virus in tomato and cucurbits (Kanakala et al. 2013). From an epidemiological point of view, these transcapsidation events occurring in the frame of a mixed viral infection can have a huge influence on the spread of a given virus, allowing it to be putatively transmitted by new vectors and arriving in new hosts and thus contributing to speeding up speciation events. In fact, recent taxonomic proposals, based on the similarities of viral polymerases (Wolf et al. 2018), argue in favor of evolutionary processes involving capture and switching of capsid genes, with mixed infections representing a key step to explain how these kinds of events could happen.

As mentioned previously, viruses are able to manipulate the host plant using different strategies that modify the vector biology, fitness, and behavior and consequently might have an impact on virus transmission and disease dynamics (Fereres and Moreno 2009). This is known as indirect mutualism and confers advantages to the vector that would result in an increase of virus transmission and, consequently, spread (Li et al. 2014). Such modifications in the host mainly rely on nutritional changes and on a manipulation of the defense responses, making the plant more attractive and suitable for 
the vector (Bak et al. 2017; Casteel and Falk 2016; Casteel et al. 2014, 2015; Li et al. 2014; Luan et al. 2014). This process is not random and the host alterations are strongly related to the transmission mode of each virus (Mauck 2016; Mauck et al. 2012). Briefly, plant viruses transmitted by insects are classified in two major groups, each one subdivided in two more groups, according to some parameters needed for acquisition, retention and inoculation. The time duration of those periods is related to the tissue tropism and the localization inside the host plant and to factors inside the insect. In the first mode of transmission, called "noncirculative," the virus does not need to enter the internal cavity of the insect body crossing cellular barriers, and the virion particles are retained in the stylet or foregut region of the vector. If the retention of the virus in the vector is brief (seconds to minutes), viruses are classified in the subgroup showing a "nonpersistent" transmission mode. If it takes minutes to hours, they are classified as "semipersistent." On the other hand, viruses that cross cellular barriers and reach the body cavity of the insect to end up in the salivary glands are named "circulative" or "persistent." If they only circulate inside the vector, they are classified as "nonpropagative"; if there is virus multiplication inside the insect, the viruses are called "propagative" (Casteel and Falk 2016; Kaur et al. 2016; Mauck et al. 2018). Thus, a host plant that is modified to be attractive (by visual and olfactory clues), even if its quality as feed for a phytophagous insect is reduced, will be well adapted for a more efficient transmission of a nonpersistent virus: the vector is first attracted to the infected plant, but when it probes on it (and thus acquires the virus in a brief period of time), the insect does not receive enough reward to colonize and remain in the plant and then goes to another plant carrying the virus. On the other hand, viruses that are transmitted in a semipersistent or persistent manner will get benefit if they manipulate the host to promote long-term feeding, thus favoring acquisition of the virus (Mauck et al. 2012). These attraction-repulsion processes can be quite dynamic, and some works have described that feeding preferences and behavior of vectors could change after virus acquisition (Ingwell et al. 2012; Moreno-Delafuente et al. 2013; Rajabaskar et al. 2014). Collectively, all of these studies suggest that viruses might have been favored by natural selection to adopt strategies to enhance their transmissibility/dispersion in the context of mixed infections, using different means for that purpose, ranging from altering vector behavior via controlling vector interactions with their host plants to other mechanisms controlling transmissibility. The last column in the upper panel of Figure 1 illustrates that vectors can be essential parts of the payoff mechanisms achieved and favored during mixed infections.

\section{IMPACT ON PLANTS}

The host plant is the organism to be preserved in agricultural production; consequently, attention concerning the outcomes of mixed viral infections, considered as pathogenic attacks, has been mainly focused on synergistic or antagonistic responses. We previously mentioned such interactions in the previous sections, and an extensive catalog of known cases is provided in Tables 1 and 2 , with comments primarily dedicated to provide information on how the different host plants are impacted by the simultaneous presence of the viruses mentioned. In this section, we will add some additional comments about a few cases that illustrate the wide variety of effects caused by the presence of multiple viruses in a host plant, particularly effects that go beyond the expected additive response to the individual viruses.

An example of host modification induced by a mixed infection can be found in grapes of plants infected with isolates of Grapevine leafroll-associated virus 1, Grapevine virus A, and Rupestris stem pitting-associated virus (Giribaldi et al. 2011). A proteomic analysis of samples from such mixed-infected plants revealed several changes in the host, with an expected major influence in the oxidative stress responses (in the fruit skin), and in the cell structure (in the pulp). The oxidative stress responses can be induced by biotic stresses, including several pathogens (Demidchik 2015; Muthamilarasan and Prasad 2013). On the other hand, the alterations in cell structure might be linked to the cytoskeleton and the movement of viruses (Henry et al. 2006; Lucas 2006).

Another key element in the responses of plants toward viruses is RNA silencing or the post-transcriptional gene silencing pathways. RNA silencing is present in all eukaryotes and regulates many essential processes, such as chromatin modification, DNA methylation, and transposon activity, among many others, relying on activity of several types of the so-called "small RNAs." In plants, RNA silencing is also one of the most important antiviral defense systems induced in response to both RNA and DNA viruses (Baulcombe 2004; Csorba et al. 2009; Vaucheret 2006; Wang et al. 2012). We have already anticipated in previous sections the importance of the mechanisms of RNA silencing for the outcome of mixed infections. In fact, likely all plant viruses encode at least one RNA silencing suppressor (Csorba et al. 2015); therefore, we should consider that at least two of them might be acting simultaneously during mixed infections. As indicated, the numerous cases of potyviruses contributing to synergistic responses during multiple infections have been associated with the strong activity of an HC-Pro as an RNA silencing suppressor (Pruss et al. 1997). Also within the same family, Potyviridae, a deep-sequencing study carried out in wheat showed that the synergistic mixed infection caused by the combination of the tritimovirus Wheat streak mosaic virus (WSMV) and the poacevirus Triticum mosaic virus (TriMV) resulted in major changes in the endogenous small RNA profile of the host plant, with an expected impact on the defense responses that differed between single and mixed infections (Tatineni et al. 2014).

The influence of the host plant on the outcome of viral mixed infections was mentioned previously, and there are some additional examples in Table 1. It has also been reported that in some synergistic viral combinations, the outcome varies depending on the host plant cultivar. For instance, the previously cited synergistic interaction between WSMV and TriMV induced different disease outcomes depending on the wheat cultivar (Tatineni et al. 2010). Other examples illustrate the influence of the cultivar in the outcome of the mixed infection, such as coinfections between (i) ToCV and TICV, (ii) PVX and PVY or Tobacco etch virus, and (iii) Pepper huasteco virus and Pepper golden mosaic virus (Gonzalez-Jara et al. 2004; MéndezLozano et al. 2003; Wintermantel et al. 2008). All of these cases likely reflect differences in the RNA silencing and antiviral responses of the host in a way that might play important roles not only in the establishment but also in the development of the disease. As a consequence, the management of viral diseases through control measures would need to consider the effects of mixed infections. Particularly worrisome would be the risk of compromising genetic resistance, as in the case of ToCV and TSWV discussed previously (García-Cano et al. 2006). Further investigations will be useful to determine whether other resistances can be compromised as well by the combined actions of viruses during mixed infections.

\section{CONCLUDING REMARKS}

In this review, we have pointed out several aspects related to mixed viral infections that support their great relevance not only for pathology but also for plant virus ecology and epidemiology. These two latter disciplines are partially related but deserve specific attention. When considering ecology, we refer to the interactions of the virus populations with the environment and its components, whereas the term "epidemiology" is more linked to the disease caused and how the virus is spread in the frame of complex associations between the viruses and the host plants, passing through the critically important participation of vectors (Jones 2014). Understanding why and how 
pathogenic viruses can spread in a given ecosystem is the main challenge of epidemiology but the factors controlling the spread become more complex in a mixed infection scenario, and it is absolutely essential to understand them in order to build effective strategies to control the frequent diseases caused by multiple viral infections.
To prevent the negative effects of mixed infections, an important area of work is to develop methods or tools that interfere with transmission by vectors. As mentioned previously, the dispersion of the majority of plant viruses relies on the action of vectors as an efficient way to overcome the sessile nature of the plants on the one hand and to provide effective means to cross the strong cell wall

TABLE 2

Examples of mixed infections involving more than two viruses (or subviral/associated elements) simultaneously found in the same individual plant

\begin{tabular}{|c|c|c|c|}
\hline$V_{\text {Viruses }}^{a}$ & Host $^{b}$ & Comments & References \\
\hline $\begin{array}{l}\text { Australian grapevine viroid (AGV) (Apscaviroid), Grapevine } \\
\text { leafroll-associated virus-9 (GLRaVs) (Ampelovirus), } \\
\text { Grapevine rupestris stem pitting-associated virus } \\
\text { (GRSPaV) (Foveavirus), Grapevine rupestris vein- } \\
\text { feathering virus (GRVFV) (Marafivirus), Grapevine Syrah } \\
\text { virus-1 (GSYV-1) (Marafivirus), Grapevine yellow speckle } \\
\text { viroid (GYSVd) (Apscaviroid), Hop stunt viroid (HSVd) } \\
\text { (Hostuviroid), or Potato spindle tuber viroid (PSTVd) } \\
\text { (Pospiviroid) }\end{array}$ & $\begin{array}{l}\text { Grapevine (Vitis } \\
\text { vinifera) }\end{array}$ & $\begin{array}{l}\text { Example of grapevine leafroll } \\
\text { disease. Sequencing analysis } \\
\text { of RNAs from a grapevine } \\
\text { plant showing decline } \\
\text { symptoms revealed the } \\
\text { presence of up to seven } \\
\text { different viruses and viroids } \\
\text { in the same individual host }\end{array}$ & $\begin{array}{l}\text { Al Rwahnih et al. (2009) } \\
\text { and Naidu et al. } \\
\text { (2015) }\end{array}$ \\
\hline $\begin{array}{l}\text { Carrot red leaf virus (CRLV) (Polerovirus), Carrot mottle } \\
\text { virus (CMoV) (Umbravirus), Carrot red leaf virus- } \\
\text { associated RNA (CtRLVaRNA) }\end{array}$ & $\begin{array}{l}\text { Carrot (Daucus } \\
\text { carota) }\end{array}$ & $\begin{array}{l}\text { Causal agents of carrot motley } \\
\text { dwarf disease. Synergism }\end{array}$ & $\begin{array}{l}\text { Naseem et al. (2016), } \\
\text { Vercruysse et al. } \\
\text { (2000), and Watson } \\
\text { et al. (1998) }\end{array}$ \\
\hline $\begin{array}{l}\text { Ethiopian tobacco bushy top virus (ETBTV) (Umbravirus), } \\
\text { Potato leafroll virus (PLRV (Polerovirus), Satellite RNA } \\
\text { of ETBTV (SatRNA-E) }\end{array}$ & $\begin{array}{l}\text { Tobacco } \\
\text { (Nicotiana } \\
\text { tabacum) } \\
\end{array}$ & $\begin{array}{l}\text { Recently emerged tobacco } \\
\text { bushy top disease (TBTD) } \\
\text { in Ethiopia. Synergism }\end{array}$ & Abraham et al. (2014) \\
\hline $\begin{array}{l}\text { SPCSV (Crinivirus), SPFMV (Potyvirus), SPMMV } \\
\text { (/pomovirus) }\end{array}$ & $\begin{array}{l}\text { Sweet potato } \\
\text { (I. batatas) }\end{array}$ & $\begin{array}{l}\text { Synergism between SPCSV + } \\
\text { SPFMV or SPMMV, and } \\
\text { SPCSV + SPFMV + SPMMV. } \\
\text { Neutralism between SPMMV } \\
\text { and SPFMV }\end{array}$ & Mukasa et al. (2006) \\
\hline $\begin{array}{l}\text { Tobacco bushy top virus (TBTV) (Umbravirus), Tobacco } \\
\text { vein distorting virus (TVDV) (Polerovirus), Satellite RNA } \\
\text { of TBTV (Sat-TBTV), Tobacco vein distorting virus } \\
\text { associate RNA (TVDVaRNA) }\end{array}$ & $\begin{array}{l}\text { Tobacco } \\
\text { (N. tabacum) }\end{array}$ & $\begin{array}{l}\text { Causal agents of the TBTD in } \\
\text { several African countries and } \\
\text { in China. Synergism and } \\
\text { efficient aphid transmission } \\
\text { reported in field conditions }\end{array}$ & Liu et al. (2014) \\
\hline
\end{tabular}

a Viruses are listed in alphabetical order with their acronym and include the taxonomic adscription (genus) in parentheses.

b Common names and scientific names are used to identify hosts. 
and deliver viruses into the susceptible parts of the cell on the other hand. Usually, a viral infection begins with the specific interaction of the vector and the virus, mediated by proteins from both (Gutiérrez et al. 2013). As discussed in this review, in mixed infections, responses and changes can be seen both on vectors and viruses and can influence subsequent virus transmission. Thus, understanding in detail those modifications may be essential to interfere with key steps in virus-vector interactions and interrupt the viral cycle, limiting the spread of the infection (Whitfield and Rotenberg 2015).

The knowledge generated by the study of mixed viral infections could become a rich source of useful information to design effective control measures or even to engineer resistant plants against viruses. As mentioned in the section on the impact on viruses, one example of this latter strategy is represented by crossprotection, based on the antagonism between viruses and consisting of the activation of plant defenses (e.g., the RNA silencing mechanisms mentioned) by the first virus, thus preventing or alleviating the damaging infection by the second virus. This strategy has been successfully applied to protect plants of high economic interest, such as citrus, cucurbits, and papaya, through inoculation of plants with a mild strain of a virus, preventing the infection by a more virulent strain in the field (Ziebell and Carr 2010). However, we must recognize that the complexities of the interactions require more investigation. Indeed, when designing strategies to engineer resistant plants against viruses, it is worth taking into account the impact that possible mixed infections in nature can have. One relevant example reports the expression of an artificial microRNA targeting the viral RNA silencing suppressor HC-Pro of Turnip mosaic virus (TuMV) in Arabidopsis thaliana transgenic plants. High levels of resistance against the infection by the homologous virus were observed; however, if the plant was previously infected by Tobacco rattle virus, Cauliflower mosaic virus, or CMV, the resistance was lost and TuMV was able to infect the plant in the frame of a mixed infection with one of the other mentioned viruses (Martínez et al. 2013).

The relationship between viruses during mixed infections can have a clear impact on the evolution of each virus involved, as the competition for the host's resources directly influences the fitness of viruses. This competition can be specified at many levels, some of which are depicted schematically in Figure 2, and others are still waiting to be analyzed in depth. Among new aspects that might require attention are those occurring as a result of the different mechanisms of translation or the conflicting situation prompted by the different codon usages of the viral partners and the host (Adams and Antoniw 2004; Belalov and Lukashev 2013; Miras et al. 2017). As a result of these competitions, mixed infections must be considered as another key factor that influences virus evolution; indeed, recent studies have proposed models to predict the long-term evolution of viruses in the frame of mixed infections (Alizon et al. 2013; Elena et al. 2014; Escriu et al. 2003; Tollenaere et al. 2016). Virulence increases can be predicted as a result of the competitive advantage of virulent parasites, because the mixed infections are prone to alter the immune defense and cause phenotypic changes in the host. Thus, a higher virulence can be consequence of the competition for resources during a mixed infection (Choisy and de Roode 2010).

To confirm these predictions and incorporate the knowledge derived into strategies of virus control, more research will be highly desirable. The presence of more than one virus in the plant also makes possible genetic exchanges between them, and even the formation of new hybrid viral species containing parts from the genomes of the distinct viral species, through reassortments or recombinations (DaPalma et al. 2010). Eventually, speciation events might take place, thus contributing to the expansion of the global virome. Moreover, it seems that the choice of a given host by a given virus is not random, and it is driven by some still unknown mechanisms, which reinforces the importance of multiple infections from an evolutionary and epidemiological point of view (Malpica et al. 2006).

Finally, recognizing the importance of mixed infections could also be instrumental for safer biotechnological exploitation of plant viruses (Pasin et al. 2019). For instance, we must take into account that when using a viral vector to express a protein or a valuable product in a susceptible plant that can be infected with another virus, we are dealing with a particular scenario of mixed infection and thus we must be aware of the possible consequences this can have on the pathosystem under study. On the other hand, the examples existing in nature where plants are able to tolerate, survive, and even thrive while supporting a multiple and highly variable virome, as in the case of sweet potatoes, deserve attention from researchers, since understanding how this particular plant can stand the multiple infections might provide hints for dealing with damage caused by viral pathogens in other crops. Genomic studies might give clues on key traits that could eventually provide wide-range tolerances to multiple stresses.

\section{ACKNOWLEDGMENTS}

We express our apologies to the authors of research works on mixed viral infections in plants that were not mentioned here as a result of space constraints. We also offer our deep gratitude for the editorial work, particularly the extended, extraordinarily detailed and insightful revisions by the anonymous reviewers.

\section{LITERATURE CITED}

Abarshi, M. M., Mohammed, I. U., Jeremiah, S. C., Legg, J. P., Kumar, P. L., Hillocks, R. J., and Maruthi, M. N. 2012. Multiplex RT-PCR assays for the simultaneous detection of both RNA and DNA viruses infecting cassava and the common occurrence of mixed infections by two cassava brown streak viruses in East Africa. J. Virol. Methods 179:176-184.

Abdullah, A. S., Moffat, C. S., Lopez-Ruiz, F. J., Gibberd, M. R., Hamblin, J., and Zerihun, A. 2017. Host-multi-pathogen warfare: Pathogen interactions in co-infected plants. Front. Plant Sci. 8:1806.

Abraham, A. D., Menzel, W., Bekele, B., and Winter, S. 2014. A novel combination of a new umbravirus, a new satellite RNA and potato leafroll virus causes tobacco bushy top disease in Ethiopia. Arch Virol. 159: 3395-3399.

Adams, M. J., and Antoniw, J. F. 2004. Codon usage bias amongst plant viruses. Arch. Virol. 149:113-135.

Al Rwahnih, M., Daubert, S., Golino, D., and Rowhani, A. 2009. Deep sequencing analysis of RNAs from a grapevine showing Syrah decline symptoms reveals a multiple virus infection that includes a novel virus. Virology 387:395-401.

Alexander, H. M., Mauck, K. E., Whitfield, A. E., Garrett, K. A., and Malmstrom, C. M. 2014. Plant-virus interactions and the agro-ecological interface. Eur. J. Plant Pathol. 138:529-547.

Alizon, S., de Roode, J. C., and Michalakis, Y. 2013. Multiple infections and the evolution of virulence. Ecol. Lett. 16:556-567.

Alves-Júnior, M., Alfenas-Zerbini, P., Andrade, E. C., Esposito, D. A., Silva, F. N., da Cruz, A. C. F., Ventrella, M. C., Otoni, W. C., and Zerbini, F. M. 2009. Synergism and negative interference during co-infection of tomato and Nicotiana benthamiana with two bipartite begomoviruses. Virology 387: 257-266.

Anderson, E. J., Kline, A. S., Morelock, T. E., and Ronald, W. M. 1996. Tolerance to blackeye cowpea mosaic potyvirus not correlated with decreased virus accumulation or protection from cowpea stunt disease. Plant Dis. 80:847-852.

Anjos, J. R., Jarlfors, U., and Ghabrial, S. A. 1992. Soybean mosaic potyvirus enhances the titer of two comoviruses in dually infected soybean plants. Phytopathology 82:1022-1027.

Bak, A., Cheung, A. L., Yang, C., Whitham, S. A., and Casteel, C. L. 2017. A viral protease relocalizes in the presence of the vector to promote vector performance. Nat. Commun. 8:14493.

Baltenberger, D. E., Ohm, H. W., and Foster, J. E. 1987. Reactions of oat, barley, and wheat to infection with barley yellow dwarf virus isolates. Crop Sci. 27:195.

Baulcombe, D. 2004. RNA silencing in plants. Nature 431:356-363.

Baulcombe, D. C., Lloyd, J., Manoussopoulos, I. N., Roberts, I. M., and Harrison, B. D. 1993. Signal for potyvirus-dependent aphid transmission of 
potato aucuba mosaic virus and the effect of its transfer to potato virus X. J. Gen. Virol. 74:1245-1253.

Belalov, I. S., and Lukashev, A. N. 2013. Causes and implications of codon usage bias in RNA viruses. PLoS One 8:e56642.

Bosque-Pérez, N. A., and Eigenbrode, S. D. 2011. The influence of virusinduced changes in plants on aphid vectors: Insights from luteovirus pathosystems. Virus Res. 159:201-205.

Bourdin, D., and Lecoq, H. 1991. Evidence that heteroencapsidation between two potyviruses is involved in aphid transmission of a non-aphidtransmissible isolate from mixed infections. Phytopathology 81: 1459-1464.

Briddon, R. W., Martin, D. P., Roumagnac, P., Navas-Castillo, J., Fiallo-Olivé, E., Moriones, E., Lett, J. M., Zerbini, F. M., and Varsani, A. 2018. Alphasatellitidae: A new family with two subfamilies for the classification of geminivirusand nanovirus-associated alphasatellites. Arch. Virol. 163:2587-2600.

Byamukama, E., Tatineni, S., Hein, G. L., Graybosch, R. A., Baezinger, P. S., French, R., and Wegulo, S. N. 2012. Effects of single and double infections of winter wheat by Triticum mosaic virus and Wheat streak mosaic virus on yield determinants. Plant Dis. 96:859-864.

Calvert, L. A., and Ghabrial, S. A. 1983. Enhancement by Soybean mosaic virus of Bean pod mottle virus titer in doubly infected soybean. Phytopathology 73:992-997.

Carvajal-Yepes, M., Olaya, C., Lozano, I., Cuervo, M., Castaño, M., and Cuellar, W. J. 2014. Unraveling complex viral infections in cassava (Manihot esculenta Crantz) from Colombia. Virus Res. 186:76-86.

Casteel, C. L., De Alwis, M., Bak, A., Dong, H., Whitham, S. A., and Jander, G. 2015. Disruption of ethylene responses by Turnip mosaic virus mediates suppression of plant defense against the green peach aphid vector. Plant Physiol. 169:209-218.

Casteel, C. L. and Falk, B. W. 2016. Plant virus-vector interactions: More than just for virus transmission. Pages 217-240 in: Current Research Topics in Plant Virology. A. Wang and X. Zhou, eds. Springer, Cham, Swizterland.

Casteel, C. L., Yang, C., Nanduri, A. C., De Jong, H. N., Whitham, S. A., and Jander, G. 2014. The NIa-Pro protein of Turnip mosaic virus improves growth and reproduction of the aphid vector, Myzus persicae (green peach aphid). Plant J. 77:653-663.

Chatzivassiliou, E. K., Moschos, E., Gazi, S., Koutretsis, P., and Tsoukaki, M. 2008. Infection of potato crops and seeds with Potato virus $Y$ and Potato leafroll virus in Greece. J. Plant Pathol. 90:253-261.

Chávez-Calvillo, G., Contreras-Paredes, C. A., Mora-Macias, J., Noa-Carrazana, J. C., Serrano-Rubio, A. A., Dinkova, T. D., Carrillo-Tripp, M., and Silva-Rosales, L. 2016. Antagonism or synergism between papaya ringspot virus and papaya mosaic virus in Carica papaya is determined by their order of infection. Virology 489:179-191.

Chen, Z., Tan, J. Y., Wen, Y., Niu, S., and Wong, S. M. 2012. A game-theoretic model of interactions between hibiscus latent Singapore virus and tobacco mosaic virus. PLoS One 7:e37007.

Choi, S. K., Yoon, J. Y., Ryu, K. H., Choi, J. K., Palukaitis, P., and Park, W. M. 2002. Systemic movement of a movement-deficient strain of Cucumber mosaic virus in zucchini squash is facilitated by a cucurbit-infecting potyvirus. J. Gen. Virol. 83:3173-3178.

Choisy, M., and de Roode, J. C. 2010. Mixed infections and the evolution of virulence: Effects of resource competition, parasite plasticity, and impaired host immunity. Am. Nat. 175:E105-E118.

Clark, C. A., Davis, J. A., Abad, J. A., Cuellar, W. J., Fuentes, S., Kreuze, J. F., Gibson, R. W., Mukasa, S. B., Tugume, A. K., Tairo, F. D., and Valkonen, J. P. T. 2012. Sweetpotato viruses: 15 years of progress on understanding and managing complex diseases. Plant Dis. 96:168-185

Creamer, R., and Falk, B. W. 1990. Direct detection of transcapsidated barley yellow dwarf luteoviruses in doubly infected plants. J. Gen. Virol. 71: 211-217.

Csorba, T., Kontra, L., and Burgyán, J. 2015. Viral silencing suppressors: Tools forged to fine-tune host-pathogen coexistence. Virology 479-480:85-103.

Csorba, T., Pantaleo, V., and Burgyán, J. 2009. RNA silencing: An antiviral mechanism. Adv. Virus Res. 75:35-71, 230.

Dáder, B., Moreno, A., Viñuela, E., and Fereres, A. 2012. Spatio-temporal dynamics of viruses are differentially affected by parasitoids depending on the mode of transmission. Viruses 4:3069-3089.

Damirdagh, I. S., and Ross, A. F. 1967. A marked synergistic interaction of potato viruses X and Y in inoculated leaves of tobacco. Virology 31:296-307.

DaPalma, T., Doonan, B. P., Trager, N. M., and Kasman, L. M. 2010. A systematic approach to virus-virus interactions. Virus Res. 149:1-9.

De, S., Chavez-Calvillo, G., Wahlsten, M., and Mäkinen, K. 2018. Disruption of the methionine cycle and reduced cellular gluthathione levels underlie potex-potyvirus synergism in Nicotiana benthamiana. Mol. Plant Pathol. 19:1820-1835.

Demidchik, V. 2015. Mechanisms of oxidative stress in plants: From classical chemistry to cell biology. Environ. Exp. Bot. 109:212-228.
Demski, J. W., and Jellu, M. D. 1975. Single and double virus infection of soybean: Plant characteristics and chemical composition. Phytopathology 65:1154-1156.

Díaz-Muñoz, S. L. 2019. Uncovering virus-virus interactions by unifying approaches and harnessing high-throughput tools. mSystems 4: e00121-19.

Dietzgen, R. G., Mann, K. S., and Johnson, K. N. 2016. Plant virus-insect vector interactions: Current and potential future research directions. Viruses $8: 303$.

Domingo-Calap, M. L., Moreno, A. B., Díaz-Pendón, J. A., Moreno, A., Fereres, A., and López-Moya, J. J. 2020. Assessing the impact on virus transmission and insect vector behavior of a viral mixed infection in melon. Phytopathology 110:174-186.

Donaire, L., Burgyán, J., and García-Arenal, F. 2016. RNA silencing may play a role in but is not the only determinant of the multiplicity of infection. J. Virol. 90:553-561.

Duffus, J. E., Liu, H.-Y., and Wisler, G. C. 1996. Tomato infectious chlorosis virus-A new clostero-like virus transmitted by Trialeurodes vaporariorum. Eur. J. Plant Pathol. 102:219-226.

Elena, S. F., Agudelo-romero, P., and Lali, J. 2009. The evolution of viruses in multi-host fitness landscapes. Open Virol. J. 3:1-6.

Elena, S. F., Bernet, G. P., and Carrasco, J. L. 2014. The games plant viruses play. Curr. Opin. Virol. 8:62-67.

Escriu, F., Fraile, A., and García-Arenal, F. 2003. The evolution of virulence in a plant virus. Evolution 57:755-765.

Falk, B. W., Chin, L.-S., and Duffus, J. E. 1989. Complementary DNA cloning and hybridization analysis of beet western yellows luteovirus RNAs. J. Gen. Virol. 70:1301-1309.

Falk, B. W., and Duffus, J. E. 1984. Identification of small single- and double-stranded RNAs associated with severe symptoms in Beet western yellows virus-infected Capsella bursa-pastoris. Phytopathology 74 : 1224-1229.

Fattouh, F. A. 2003. Double infection of a cucurbit host by zucchini yellow mosaic virus and cucumber mosaic virus. Pak. J. Plant Pathol. 2:85-90.

Fereres, A., and Moreno, A. 2009. Behavioural aspects influencing plant virus transmission by homopteran insects. Virus Res. 141:158-168.

García-Cano, E., Resende, R. O., Fernández-Muñoz, R., and Moriones, E. 2006. Synergistic interaction between Tomato chlorosis virus and Tomato spotted wilt virus results in breakdown of resistance in tomato. Phytopathology 96:1263-1269.

Giribaldi, M., Purrotti, M., Pacifico, D., Santini, D., Mannini, F., Caciagli, P., Rolle, L., Cavallarin, L., Giuffrida, M. G., and Marzachì, C. 2011. A multidisciplinary study on the effects of phloem-limited viruses on the agronomical performance and berry quality of Vitis vinifera cv. Nebbiolo. J. Proteomics 75:306-315.

Goldberg, K.-B., and Brakke, M. 1987. Concentration of Maize chlorotic mottle virus increased in mixed infections with Maize dwarf mosaic virus, strain B. Phytopathology 77:162-167.

Gómez, P., Sempere, R. N., Amari, K., Gómez-Aix, C., and Aranda, M. A. 2010. Epidemics of Tomato torrado virus, Pepino mosaic virus and Tomato chlorosis virus in tomato crops: Do mixed infections contribute to torrado disease epidemiology? Ann. Appl. Biol. 156:401-410.

Gómez, P., Sempere, R. N., Elena, S. F., and Aranda, M. A. 2009. Mixed infections of Pepino mosaic virus strains modulate the evolutionary dynamics of this emergent virus. J. Virol. 83:12378-12387.

González-Jara, P., Atencio, F. A., Martínez-García, B., Barajas, D., Tenllado, F., and Díaz-Ruíz, J. R. 2005. A single amino acid mutation in the Plum pox virus helper component-proteinase gene abolishes both synergistic and RNA silencing suppression activities. Phytopathology 95:894-901.

González-Jara, P., Fraile, A., Canto, T., and García-Arenal, F. 2009. The multiplicity of infection of a plant virus varies during colonization of its eukaryotic host. J. Virol. 83:7487-7494.

Gonzalez-Jara, P., Tenllado, F., Martinez-García, B., Atencio, F. A., Barajas, D., Vargas, M., Diaz-Ruiz, J., and Diaz-Ruiz, J. R. 2004. Host-dependent differences during synergistic infection by Potyviruses with potato virus X. Mol. Plant Pathol. 5:29-35.

Goodman, R. M., and Ross, A. F. 1974. Enhancement by potato virus Y of potato virus $\mathrm{X}$ synthesis in doubly infected tobacco depends on the timing of invasion by the viruses. Virology 58:263-271.

Gutiérrez, S., Michalakis, Y., and Blanc, S. 2012. Virus population bottlenecks during within-host progression and host-to-host transmission. Curr. Opin. Virol. 2:546-555.

Gutiérrez, S., Michalakis, Y., Van Munster, M., and Blanc, S. 2013. Plant feeding by insect vectors can affect life cycle, population genetics and evolution of plant viruses. Funct. Ecol. 27:610-622.

Gutiérrez, S., Yvon, M., Thébaud, G., Monsion, B., Michalakis, Y., and Blanc, S. 2010. Dynamics of the multiplicity of cellular infection in a plant virus. PLoS Pathog. 6:e1001113. 
Hacker, D. L., and Fowler, B. C. 2000. Complementation of the host range restriction of southern cowpea mosaic virus in bean by southern bean mosaic virus. Virology 266:140-149.

Hameed, A., Iqbal, Z., Asad, S., and Mansoor, S. 2014. Detection of multiple potato viruses in the field suggests synergistic interactions among potato viruses in Pakistan. Plant Pathol. J. 30:407-415.

Henry, T., Gorvel, J. P., and Méresse, S. 2006. Molecular motors hijacking by intracellular pathogens. Cell. Microbiol. 8:23-32.

Hobbs, H. A., and McLaughlin, M. R. 1990. A non-aphid-transmissible isolate of Bean yellow mosaic virus-Scott that is transmissible from mixed infections with Pea mosaic virus-204-1. Phytopathology 80:268-272.

Ingwell, L. L., Eigenbrode, S. D., and Bosque-Pérez, N. A. 2012. Plant viruses alter insect behavior to enhance their spread. Sci. Rep. 2:578.

International Committee on Virus Taxonomy. 2018. ICTV Master Species List $2018 \mathrm{~b}$ version 2 . https://talk.ictvonline.org/files/master-species-lists $/ \mathrm{m} / \mathrm{msl} / 8266$

Jacobson, A. L., Duffy, S., and Sseruwagi, P. 2018. Whitefly-transmitted viruses threatening cassava production in Africa. Curr. Opin. Virol. 33:167-176.

Jeger, M. J., Chen, Z., Powell, G., Hodge, S., and van den Bosch, F. 2011a. Interactions in a host plant-virus-vector-parasitoid system: Modelling the consequences for virus transmission and disease dynamics. Virus Res. 159:183-193.

Jeger, M. J. J., van den Bosch, F., and Madden, L. V. V. 2011b. Modelling virus- and host-limitation in vectored plant disease epidemics. Virus Res. 159:215-222.

Jones, R. A. C. 2014. Plant virus ecology and epidemiology: Historical perspectives, recent progress and future prospects. Ann. Appl. Biol. 164: 320-347.

Kanakala, S., Jyothsna, P., Shukla, R., Tiwari, N., Veer, B. S., Swarnalatha, P., Krishnareddy, M., and Malathi, V. G. 2013. Asymmetric synergism and heteroencapsidation between two bipartite begomoviruses, Tomato leaf curl New Delhi virus and Tomato leaf curl Palampur virus. Virus Res. 174:126-136.

Karyeija, R. F., Kreuze, J. F., Gibson, R. W., and Valkonen, J. P. 2000. Synergistic interactions of a potyvirus and a phloem-limited crinivirus in sweet potato plants. Virology 269:26-36.

Kassanis, B. 1961. The transmission of Potato aucuba mosaic virus by aphids from plants also infected by potato viruses A or Y. Virology 13:93-97.

Kaur, N., Hasegawa, D. K., Ling, K.-S., and Wintermantel, W. M. 2016. Application of genomics for understanding plant virus-insect vector interactions and insect vector control. Phytopathology 106:1213-1222.

Kokkinos, C. D., and Clark, C. A. 2006. Interactions among Sweet potato chlorotic stunt virus and different potyviruses and potyvirus strains infecting sweetpotato in the United States. Plant Dis. 90:1347-1352.

Koonin, E. V., and Dolja, V. V. 2018. Metaviromics: A tectonic shift in understanding virus evolution. Virus Res. 246:A1-A3.

Lee, Y.-S., and Ross, J. P. 1972. Top necrosis and cellular changes in soybean doubly infected by soybean mosaic and bean pod mottle viruses. Phytopathology 62:839-845.

Legg, J. P., and Fauquet, C. M. 2004. Cassava mosaic geminiviruses in Africa. Plant Mol. Biol. 56:585-599.

Legg, J. P., Lava Kumar, P., Makeshkumar, T., Tripathi, L., Ferguson, M., Kanju, E., Ntawuruhunga, P., and Cuellar, W. 2015. Cassava virus diseases: Biology, epidemiology, and management. Adv. Virus Res. 91:85-142.

Li, R., Weldegergis, B. T., Li, J., Jung, C., Qu, J., et al. 2014. Virulence factors of geminivirus interact with myc2 to subvert plant resistance and promote vector performance. Plant Cell 26:4991-5008.

Li, S., Zhang, T., Zhu, Y., and Zhou, G. 2017. Co-infection of two reoviruses increases both viruses accumulation in rice by up-regulating of viroplasm components and movement proteins bilaterally and RNA silencing suppressor unilaterally. Virol. J. 14:150.

Liu, F., Tan, G., Li, X., Chen, H., Li, R., and Li, F. 2014. Simultaneous detection of four causal agents of tobacco bushy top disease by a multiplex one-step RT-PCR. J. Virol. Methods 205:99-103.

Luan, J. B., Wang, X. W., Colvin, J., and Liu, S. S. 2014. Plant-mediated whitefly-begomovirus interactions: Research progress and future prospects. Bull. Entomol. Res. 104:267-276.

Lucas, W. J. 2006. Plant viral movement proteins: Agents for cell-to-cell trafficking of viral genomes. Virology 344:169-184.

Macedo, M. A., Barreto, S. S., Hallwass, M., and Inoue-Nagata, A. K. 2014. High incidence of Tomato chlorosis virus alone and in mixed infection with begomoviruses in two tomato fields in the Federal District and Goiás state, Brazil. Trop. Plant Pathol. 39:449-452.

Mahuku, G., Lockhart, B. E., Wanjala, B., Jones, M. W., Kimunye, J., et al. 2015. Maize lethal necrosis (MLN), an emerging threat to maize-based food security in sub-Saharan Africa. Phytopathology 105:956-965.

Malpica, J. M., Sacristán, S., Fraile, A., and García-Arenal, F. 2006. Association and host selectivity in multi-host pathogens. PLoS One 1:e41.

Manoussopoulos, I. N. 2001. Acquisition and retention of potato virus Y helper component in the transmission of potato aucuba mosaic virus by aphids. J. Phytopathol. 149:103-106.
Mar, T. B., Mendes, I. R., Lau, D., Fiallo-Olivé, E., Navas-Castillo, J., Alves, M. S., and Murilo Zerbini, F. 2017. Interaction between the New World begomovirus Euphorbia yellow mosaic virus and its associated alphasatellite: Effects on infection and transmission by the whitefly Bemisia tabaci. J. Gen. Virol. 98:1552-1562.

Martelli, G. P. 2014. Directory of virus and virus-like diseases of the grapevine and their agents. J. Plant Pathol. 96:1-136.

Martín, S., and Elena, S. F. 2009. Application of game theory to the interaction between plant viruses during mixed infections. J. Gen. Virol. 90:2815-2820.

Martínez, F., Elena, S. F., and Daròs, J.-A. 2013. Fate of artificial microRNAmediated resistance to plant viruses in mixed infections. Phytopathology 103:870-876.

Mascia, T., Cillo, F., Fanelli, V., Finetti-Sialer, M. M., De, S. A., Palukaitis, P., and Gallitelli, D. 2010. Characterization of the interactions between $\mathrm{Cu}$ cumber mosaic virus and Potato virus $Y$ in mixed infections in tomato. Mol. Plant-Microbe Interact. 23:1514-1524.

Mascia, T., and Gallitelli, D. 2016. Synergies and antagonisms in virus interactions. Plant Sci. 252:176-192.

Mauck, K. E. 2016. Effects of pathogens on sensory-mediated interactions between plants and insect vectors. Curr. Opin. Plant Biol. 32:53-61.

Mauck, K. E., Bosque-Pérez, N. A., Eigenbrode, S. D., De Moraes, C. M., and Mescher, M. C. 2012. Transmission mechanisms shape pathogen effects on host-vector interactions: Evidence from plant viruses. Funct. Ecol. 26: 1162-1175.

Mauck, K. E., Chesnais, Q., and Shapiro, L. R. 2018. Evolutionary determinants of host and vector manipulation by plant viruses. Adv. Virus Res. 101: 189-250.

Mayo, M., Ryabov, E., Fraser, G., and Taliansky, M. 2000. Mechanical transmission of Potato leafroll virus. J. Gen. Virol. 81:2791-2795.

Méndez-Lozano, J., Torres-Pacheco, I., Fauquet, C. M., and Rivera-Bustamante, R. F. 2003. Interactions between geminiviruses in a naturally occurring mixture: Pepper huasteco virus and Pepper golden mosaic virus. Phytopathology 93:270-277.

Mingot, A., Valli, A., Rodamilans, B., San León, D., Baulcombe, D. C., García, J. A., and López-Moya, J. J. 2016. The P1N-PISPO trans-frame gene of sweet potato feathery mottle potyvirus is produced during virus infection and functions as an RNA silencing suppressor. J. Virol. 90:3543-3557.

Miralles, R., Ferrer, R., Sole, R. V., Moya, A., and Elena, S. F. 2001. Multiple infection dynamics has pronounced effects on the fitness of RNA viruses. J. Evol. Biol. 14:654-662.

Miras, M., Miller, W. A., Trunigues, V., and Aranda, M. A. 2017. Noncanonical translation in RNA viruses. Front. Plant Sci. 8:494.

Moreno-Delafuente, A., Garzo, E., Moreno, A., and Fereres, A. 2013. A plant virus manipulates the behavior of its whitefly vector to enhance its transmission efficiency and spread. PLoS One 8:e61543.

Mukasa, S. B., Rubaihayo, P. R., and Valkonen, J. P. T. 2003. Incidence of viruses and virus like diseases of sweetpotato in Uganda. Plant Dis. 87: 329-335.

Mukasa, S. B., Rubaihayo, P. R., and Valkonen, J. P. T. 2006. Interactions between a crinivirus, an ipomovirus and a potyvirus in coinfected sweetpotato plants. Plant Pathol. 55:458-467.

Murant, A. F. 1990. Dependence of groundnut rosette virus on its satellite RNA as well as on groundnut rosette assistor luteovirus for transmission by Aphis craccivora. J. Gen. Virol. 71:2163-2166.

Murant, A. F., and Goold, R. A. 1968. Purification, properties and transmission of parsnip yellow fleck, a semi-persistent, aphid-borne virus. Ann. Appl. Biol. 62:123-137.

Murant, A. F., Roberts, I. M., and Elnagar, S. 1976. Association of virus like particles with the foregut of the aphid Cavariella aegopodii transmitting the semi-persistent viruses Anthriscus yellows and Parsnip yellow fleck. J. Gen. Virol. 31:47-57.

Murphy, J. F., and Bowen, K. L. 2006. Synergistic disease in pepper caused by the mixed infection of Cucumber mosaic virus and Pepper mottle virus. Phytopathology 96:240-247.

Muthamilarasan, M., and Prasad, M. 2013. Plant innate immunity: An updated insight into defense mechanism. J. Biosci. 38:433-449.

Naidu, R., Rowhani, A., Fuchs, M., Golino, D., and Martelli, G. P. 2014. Grapevine leafroll: A complex viral disease affecting a high-value fruit crop. Plant Dis. 98:1172-1185.

Naidu, R. A., Maree, H. J., and Burger, J. T. 2015. Grapevine leafroll disease and associated viruses: A unique pathosystem. Annu. Rev. Phytopathol. 53: 613-634.

Naseem, M. T., Ashfaq, M., Khan, A. M., Kiss, Z., Akhtar, K. P., and Mansoor, S. 2016. Transmission of viruses associated with carrot motley dwarf by Myzus persicae. J. Plant Pathol. 98:581-585.

Nyalugwe, E. P., Wilson, C. R., Coutts, B. A., and Jones, R. A. C. 2012. Biological properties of Potato virus $X$ in potato: Effects of mixed infection 
with Potato virus $S$ and resistance phenotypes in cultivars from three continents. Plant Dis. 96:43-54.

Pasin, F., Menzel, W., and Daròs, J. A. 2019. Harnessed viruses in the age of metagenomics and synthetic biology: An update on infectious clone assembly and biotechnologies of plant viruses. Plant Biotechnol. J. 17: 1010-1026.

Passmore, B. K., Sanger, M., Chin, L. S., Falk, B. W., and Bruening, G. 1993. Beet western yellows virus-associated RNA: An independently replicating RNA that stimulates virus accumulation. Proc. Natl. Acad. Sci. U.S.A. 90: 10168-10172.

Peñaflor, M. F. G. V., Mauck, K. E., Alves, K. J., De Moraes, C. M., and Mescher, M. C. 2016. Effects of single and mixed infections of Bean pod mottle virus and Soybean mosaic virus on host-plant chemistry and hostvector interactions. Funct. Ecol. 30:1648-1659.

Pio-Ribeiro, G., Wyatt, S. D., and Kuhn, C. W. 1978. Cowpea stunt: A disease caused by a synergistic interaction of two viruses. Phytopathology 68: 1260-1265.

Pirone, T. P., and Blanc, S. 1996. Helper-dependent vector transmission of plant viruses. Annu. Rev. Phytopathol. 34:227-247.

Pohl, D., and Wege, C. 2007. Synergistic pathogenicity of a phloem-limited begomovirus and tobamoviruses, despite negative interference. J. Gen. Virol. 88:1034-1040.

Prager, S. M., Wallis, C., and Trumble, J. T. 2015. Indirect effects of one plant pathogen on the transmission of a second pathogen and the behavior of its potato psyllid vector. Environ. Entomol. 44:1065-1075.

Pruss, G., Ge, X., Shi, X. M., Carrington, J. C., and Bowman Vance, V. 1997. Plant viral synergism: The potyviral genome encodes a broad-range pathogenicity enhancer that transactivates replication of heterologous viruses. Plant Cell 9:859-868

Rajabaskar, D., Bosque-Pérez, N. A., and Eigenbrode, S. D. 2014. Preference by a virus vector for infected plants is reversed after virus acquisition. Virus Res. 186:32-37.

Reddy, R. V. C., Dong, W., Njock, T., Rey, M. E. C., and Fondong, V. N. 2012. Molecular interaction between two cassava geminiviruses exhibiting crossprotection. Virus Res. 163:169-177.

Redinbaugh, M. G., and Stewart, L. R. 2018. Maize lethal necrosis: An emerging, synergistic viral disease. Annu. Rev. Virol. 5:301-322.

Rentería-Canett, I., Xoconostle-Cázares, B., Ruiz-Medrano, R., and RiveraBustamante, R. 2011. Geminivirus mixed infection on pepper plants: Synergistic interaction between PHYVV and PepGMV. Virol. J. 8:104.

Rey, C., and Vanderschuren, H. 2017. Cassava mosaic and Brown streak diseases: Current perspectives and beyond. Annu. Rev. Virol. 4:429-452.

Rochow, W. F. 1970. Barley yellow dwarf virus: Phenotypic mixing and vector specificity. Science 167:875-878.

Rochow, W. F. 1972. The role of mixed infections in the transmission of plant viruses by aphids. Annu. Rev. Phytopathol. 10:101-124.

Roossinck, M. J., Martin, D. P., and Roumagnac, P. 2015. Plant virus metagenomics: Advances in virus discovery. Phytopathology 105:716-727.

Roossinck, M. J., Saha, P., Wiley, G. B., Quan, J., White, J. D., Lai, H., Chavarría, F., Shen, G., and Roe, B. A. 2010. Ecogenomics: Using massively parallel pyrosequencing to understand virus ecology. Mol. Ecol. 19: 81-88

Ross, F. 1950. Local lesion formation and virus production following simultaneous inoculation with Potato virus-X and virus-Y. Phytopathology 40:24.

Ryabov, E. V., Fraser, G., Mayo, M. A., Barker, H., and Taliansky, M. 2001. Umbravirus gene expression helps Potato leafroll virus to invade mesophyll tissues and to be transmitted mechanically between plants. Virology 286: 363-372.

Sáenz, P., Salvador, B., Simón-Mateo, C., Kasschau, K. D., Carrington, J. C., and García, J. A. 2002. Host-specific involvement of the HC protein in the long-distance movement of potyviruses. J. Virol. 76:1922-1931.

Saijo, Y., and Loo, E. P. 2019. Plant immunity in signal integration between biotic and abiotic stress responses. Online publication. New Phytol. doi: 10.1111/nph.15989

Saldaña, J., Elena, S. F., and Solé, R. V. 2003. Coinfection and superinfection in RNA virus populations: A selection-mutation model. Math. Biosci. 183: 135-160.

Sanfaçon, H. 2017. Grand challenge in plant virology: Understanding the impact of plant viruses in model plants, in agricultural crops, and in complex ecosystems. Front. Microbiol. 8:860.

Sanger, M., Passmore, B., Falk, B. W., Bruening, G., Ding, B., and Lucas, W. J. 1994. Symptom severity of beet western yellows virus strain ST9 is conferred by the ST9-associated RNA and is not associated with virus release from the phloem. Virology 200:48-55.

Sardo, L., Wege, C., Kober, S., Kocher, C., Accotto, G. P., and Noris, E. 2011. RNA viruses and their silencing suppressors boost Abutilon mosaic virus, but not the Old World Tomato yellow leaf curl Sardinia virus. Virus Res. 161:170-180.
Savenkov, E. I., and Valkonen, J. P. T. 2001. Potyviral helper-component proteinase expressed in transgenic plants enhances titers of potato leaf roll virus but does not alleviate its phloem limitation. Virology 283: 285-293.

Scheets, K. 1998. Maize chlorotic mottle machlomovirus and wheat streak mosaic rymovirus concentrations increase in the synergistic disease corn lethal necrosis. Virology 242:28-38.

Senanayake, D. M. J. B., and Mandal, B. 2014. Expression of symptoms, viral coat protein and silencing suppressor gene during mixed infection of a $\mathrm{N}$-Wi strain of Potato virus $Y$ and an asymptomatic strain of Potato virus $X$. VirusDisease 25:314-321.

Simons, J. N. 1976. Aphid transmission of a nonaphid-transmissible strain of tobacco etch virus. Phytopathology 66:652-654.

Singh, R. P., and Somerville, T. H. 1987. New disease symptoms observed on field-grown potato plants with potato spindle tuber viroid and potato virus Y infections. Potato Res. 30:127-133.

Smith, K. M. 1931. On the composite nature of certain potato virus diseases of the mosaic group as revealed by the use of plant indicators and selective methods of transmission. Proc R. Soc. B. 109:251-267.

Srinivasan, R., and Alvarez, J. M. 2007. Effect of mixed viral infections (Potato virus Y-Potato leafroll virus) on biology and preference of vectors Myzus persicae and Macrosiphum euphorbiae (Hemiptera: Aphididae). J. Econ. Entomol. 100:646-655.

Stafford, C. A., Walker, G. P., and Ullman, D. E. 2011. Infection with a plant virus modifies vector feeding behavior. Proc. Natl. Acad. Sci. U.S.A. 108: 9350-9355.

Stewart, L. R., Willie, K., Wijeratne, S., Redinbaugh, M. G., Massawe, D., Niblett, C. L., Kiggundu, A., and Asiimwe, T. 2017. Johnsongrass mosaic virus contributes to maize lethal necrosis in East Africa. Plant Dis. 101: $1455-1462$.

Syller, J. 2000. Heterologous encapsidation in transmission of plant viral particles by aphid vectors. Acta Microbiol. Pol. 49:5-18.

Syller, J. 2012. Facilitative and antagonistic interactions between plant viruses in mixed infections. Mol. Plant Pathol. 13:204-216.

Syller, J. 2014. Biological and molecular events associated with simultaneous transmission of plant viruses by invertebrate and fungal vectors. Mol. Plant Pathol. 15:417-426

Syller, J., and Grupa, A. 2016. Antagonistic within-host interactions between plant viruses: Molecular basis and impact on viral and host fitness. Mol. Plant Pathol. 17:769-782.

Takeshita, M., et al. 2012. Infection dynamics in viral spread and interference under the synergism between Cucumber mosaic virus and Turnip mosaic virus. Mol. Plant-Microbe Interact. 25:18-27.

Tatineni, S., Graybosch, R. A., Hein, G. L., Wegulo, S. N., and French, R. 2010. Wheat cultivar-specific disease synergism and alteration of virus accumulation during co-infection with Wheat streak mosaic virus and Triticum mosaic virus. Phytopathology 100:230-238.

Tatineni, S., Riethoven, J. M., Graybosch, R. A., French, R., and Mitra, A. 2014. Dynamics of small RNA profiles of virus and host origin in wheat cultivars synergistically infected by Wheat streak mosaic virus and Triticum mosaic virus: Virus infection caused a drastic shift in the endogenous small RNA profile. PLoS One 9:e111577.

Tollenaere, C., Susi, H., and Laine, A. L. 2016. Evolutionary and epidemiological implications of multiple infection in plants. Trends Plant Sci. 21:80-90.

Tugume, A. K., Mukasa, S. B., and Valkonen, J. P. T. 2005. Mixed infections of four viruses, the incidence and phylogenetic relationships of sweet potato chlorotic fleck virus (Betaflexiviridae) isolates in wild species and sweetpotatoes in Uganda and evidence of distinct isolates in East Africa. PLoS One 11:e0167769.

Tzanetakis, I. E., Pathology, P., Wintermantel, W. M., Cortez, A. A., Street, E. A., Barnes, J. E., Barrett, S. M., Crops, H., Bolda, M. P., Cooperative, C., and Martin, R. R. 2006. Epidemiology of Strawberry pallidosis-associated virus and occurrence of pallidosis disease in North America. Plant Dis. 90: 1343-1346.

Untiveros, M., Fuentes, S., and Salazar, L. F. 2007. Synergistic interaction of Sweet potato chlorotic stunt virus (Crinivirus) with carla-, cucumo-, ipomo-, and potyviruses infecting sweet potato. Plant Dis. 91:669-676.

Untiveros, M., Olspert, A., Artola, K., Firth, A. E., Kreuze, J. F., and Valkonen, J. P. T. 2016. A novel sweet potato potyvirus open reading frame (ORF) is expressed via polymerase slippage and suppresses RNA silencing. Mol. Plant Pathol. 17:1111-1123.

Uyemoto, J. K., Bockelman, D. L., and Claflin, L. E. 1980. Severe outbreak of corn lethal necrosis disease in Kansas. Plant Dis. 64:99-100.

Valkonen, J. P. T. 1992. Accumulation of potato virus Y is enhanced in Solanum brevidens also infected with tobacco mosaic virus or potato spindle tuber viroid. Ann. Appl. Biol. 121:321-327.

Valli, A. A., Gallo, A., Rodamilans, B., López-Moya, J. J., and García, J. A. 2018. The HCPro from the Potyviridae family: An enviable multitasking 
helper component that every virus would like to have. Mol. Plant Pathol. 19:744-763.

Vance, V. B. 1991. Replication of potato virus X RNA is altered in coinfections with potato virus Y. Virology 182:486-494.

Vance, V. B., Berger, P. H., Carrington, J. C., Hunt, A. G., and Shi, X. M. 1995. 5' proximal potyviral sequences mediate potato virus X/potyviral synergistic disease in transgenic tobacco. Virology 206:583-590.

Vanitharani, R., Chellappan, P., Pita, J., and Fauquet, C. 2004. Differential roles of AC2 and AC4 of cassava geminiviruses in mediating synergism and suppression of posttranscriptional gene silencing. J. Virol. 78:9487-9498.

Vaucheret, H. 2006. Post-transcriptional small RNA pathways in plants: Mechanisms and regulations. Genes Dev. 20:759-771.

Vercruysse, P., Gibbs, M., Tirry, L., and Höfte, M. 2000. RT-PCR using redundant primers to detect the three viruses associated with carrot motley dwarf disease. J. Virol. Methods 88:153-161.

Wang, H., Xu, D., Pu, L., and Zhou, G. 2014. Southern rice black-streaked dwarf virus alters insect vectors' host orientation preferences to enhance spread and increase Rice ragged stunt virus co-infection. Phytopathology 104:196-201.

Wang, J., Turina, M., Medina, V., and Falk, B. W. 2009a. Synergistic interaction between the Potyvirus, Turnip mosaic virus and the Crinivirus, Lettuce infectious yellows virus in plants and protoplasts. Virus Res. 144:163-170.

Wang, J., Turina, M., Stewart, L. R., Lindbo, J., and Falk, B. W. 2009 b. Agroinoculation of the Crinivirus, Lettuce infectious yellows virus, for systemic plant infection. Virology 392:131-136.

Wang, M.-B., Masuta, C., Smith, N. A., and Shimura, H. 2012. RNA silencing and plant viral diseases. Mol. Plant-Microbe Interact. 25:1275-1285.

Wang, Y., Gaba, V., Yang, J., Palukaitis, P., and Gal-On, A. 2002. Characterization of synergy between Cucumber mosaic virus and potyviruses in cucurbit hosts. Phytopathology 92:51-58.

Watson, M. T., Tian, T., Estabrook, E., and Falk, B. W. 1998. A small RNA resembling the beet western yellows luteovirus ST9-associated RNA is a component of the California carrot motley dwarf complex. Phytopathology 88:164-170.

Wege, C., and Siegmund, D. 2007. Synergism of a DNA and an RNA virus: Enhanced tissue infiltration of the begomovirus Abutilon mosaic virus (AbMV) mediated by Cucumber mosaic virus (CMV). Virology 357:10-28.

Whitfield, A. E., and Rotenberg, D. 2015. Disruption of insect transmission of plant viruses. Curr. Opin. Insect Sci. 8:79-87.

Wintermantel, W. M., Cortez, A. A., Anchieta, A. G., Gulati-Sakhuja, A., and Hladky, L. L. 2008. Co-infection by two criniviruses alters accumulation of each virus in a host-specific manner and influences efficiency of virus transmission. Phytopathology 98:1340-1345.

Wintermantel, W. M., Fuentes, S., Chuquillanqui, C., and Salazar, L. F. 2006. First report of Beet pseudo-yellows virus and Strawberry pallidosis associated virus in strawberry in Peru. Plant Dis. 90:1457.

Wolf, Y. I., Kazlauskas, D., Iranzo, J., Lucía-Sanz, A., Kuhn, J. H., Krupovic, M., Dolja, V. V., and Koonin, E. V. 2018. Origins and evolution of the global RNA virome. MBio 9:e02329-18.

Zeng, R., Liao, Q., Feng, J., Li, D., and Chen, J. 2007. Synergy between Cucumber mosaic virus and Zucchini yellow mosaic virus on Cucurbitaceae hosts tested by real-time reverse transcription-polymerase chain reaction. Acta Biochim. Biophys. Sin. (Shanghai) 39:431-437.

Zhang, Y.-Z., Chen, Y.-M., Wang, W., Qin, X.-C., and Holmes, E. C. 2019. Expanding the RNA virosphere by unbiased metagenomics. Annu. Rev. Virol. 6:119-139.

Ziebell, H., and Carr, J. P. 2010. Cross-protection: A century of mystery. Adv. Virus Res. 76:211-264.

Zinga, I., Chiroleu, F., Legg, J., Lefeuvre, P., Kosh, E., Semballa, S., Yandia, S. P., Mandakombo, N. B., Reynaud, B., and Lett, J. 2013. Epidemiological assessment of cassava mosaic disease in Central African Republic reveals the importance of mixed viral infection and poor health of plant cuttings. Crop Prot. 44:6-12. 